\title{
A Novel Quad-Band Circularly Polarized Planar Slot Antenna using Triple Strips
}

\author{
Reshmi Dhara ${ }^{1}$ and Taraknath Kundu ${ }^{2}$ \\ ${ }^{1}$ Sikkim National Institute of Technology \\ ${ }^{2}$ National Institute of Technology Sikkim
}

May 5, 2020

\begin{abstract}
Herein a simple, compact quad-band circularly polarized monopole antenna is proposed for multisystem application. The monopole antenna is constructed via triple strip fed by the microstrip line, a ground plane on the reverse side of the substrate having a slotted square loop, and two stubs which are slotted employed transversely across the diagonal line on the square loop. This proposed antenna is simulated and fabricated to stimulate a number of resonances. Optimizations of the antenna design parameters combined the resonances, and thus obtained a wide multi impedance bandwidth (IBW). The measured multi IBW at $\mathrm{S} 11<-10 \mathrm{~dB}$ ranges from $4.63-5.47 \mathrm{GHz}, 6.08-6.59 \mathrm{GHz}, 8.26-9.59 \mathrm{GHz}, 10.05-10.42 \mathrm{GHz}$, and $11.81-$ beyond $15 \mathrm{GHz}$. The simulated quad axial ratio bands are 217, 269, 223 and $564 \mathrm{MHz}$ at centre frequencies (fc) of 5.3, 9.0, $12.1 \mathrm{and} 13.8 \mathrm{GHz}$, correspondingly. Implemented antenna radiation features are also presented and deliberated.
\end{abstract}

\section{Hosted file}

RESEARCH ARTICLE.docx available at https://authorea.com/users/301864/articles/432368-a-novelquad-band-circularly-polarized-planar-slot-antenna-using-triple-strips 


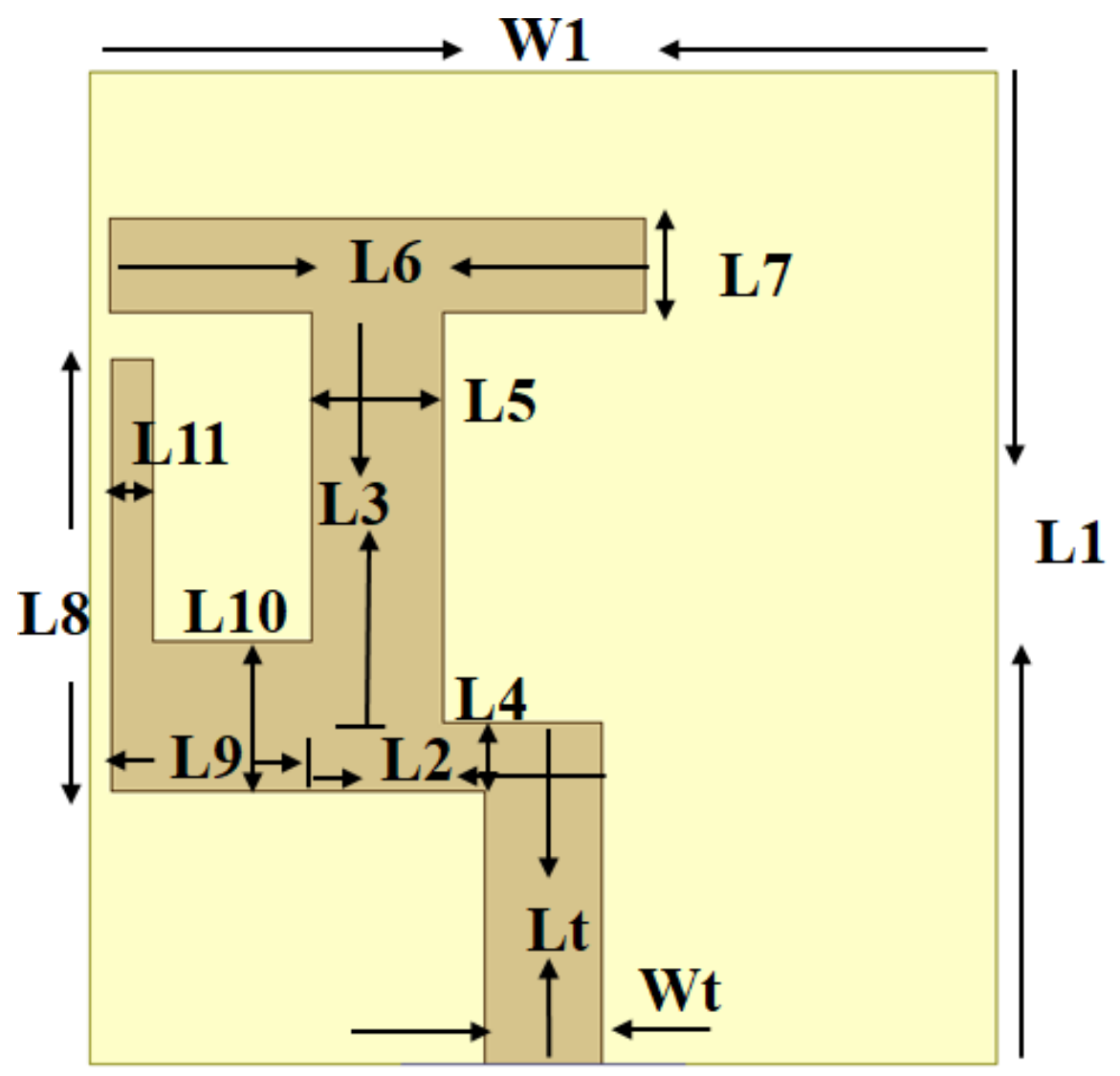




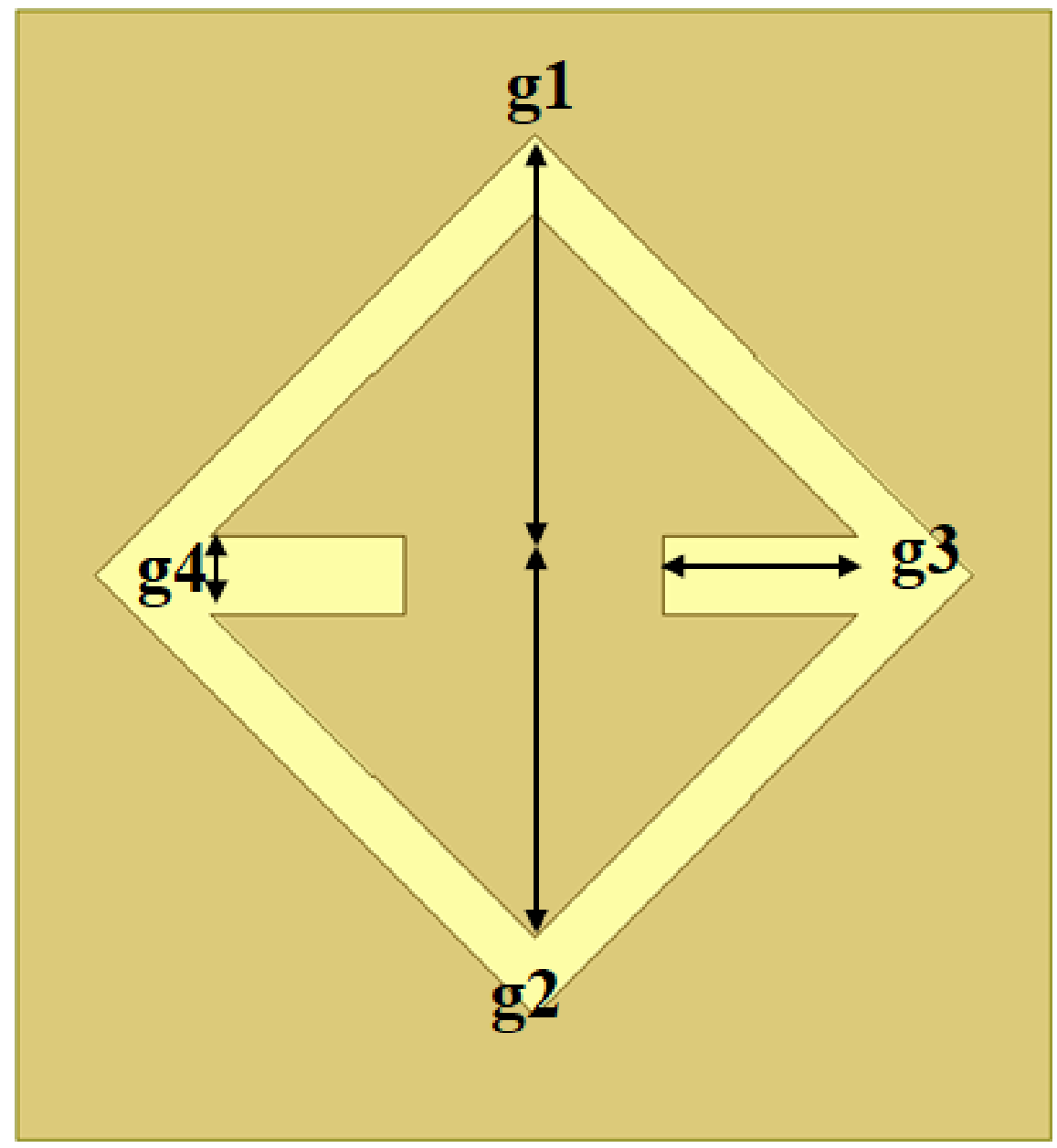




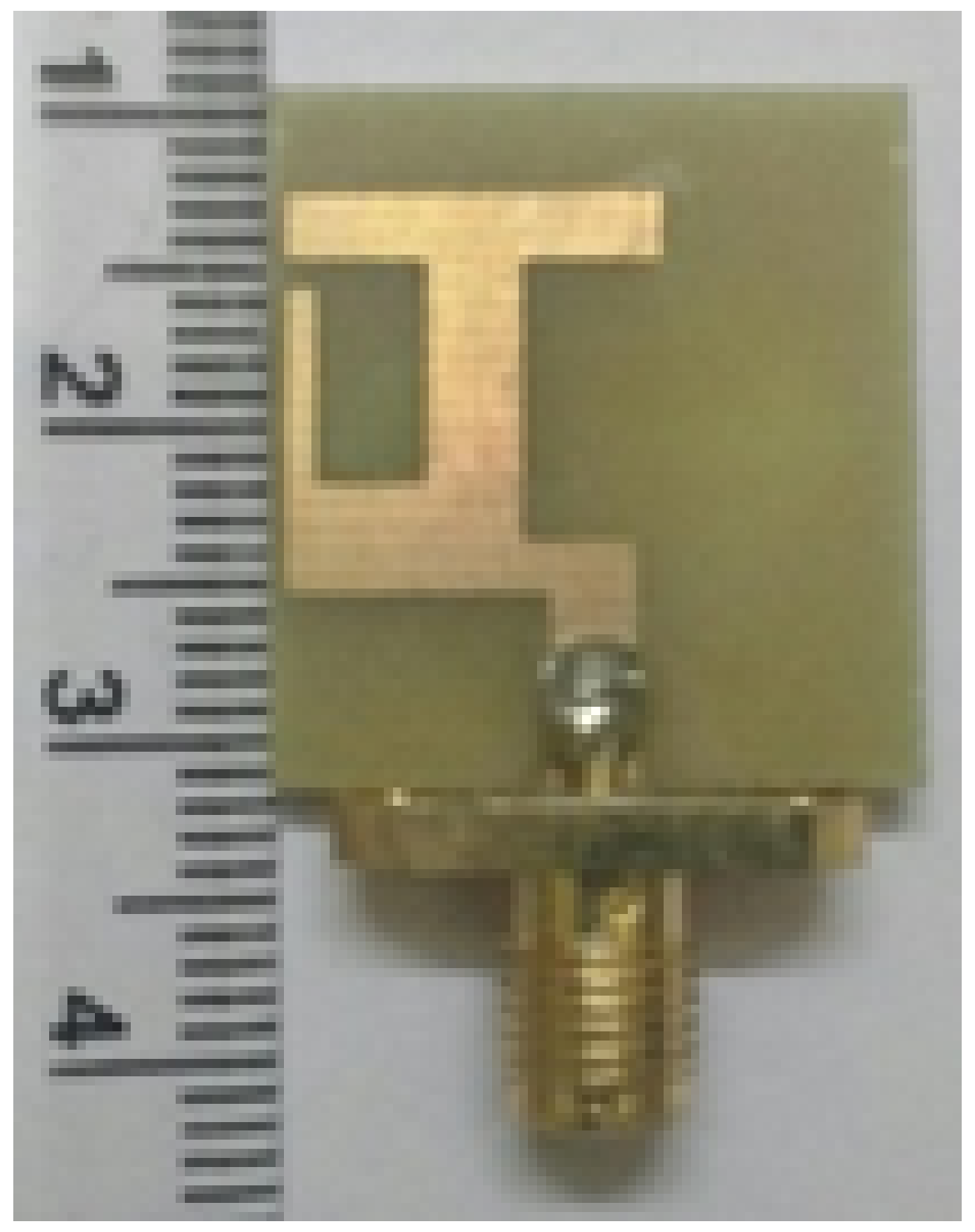




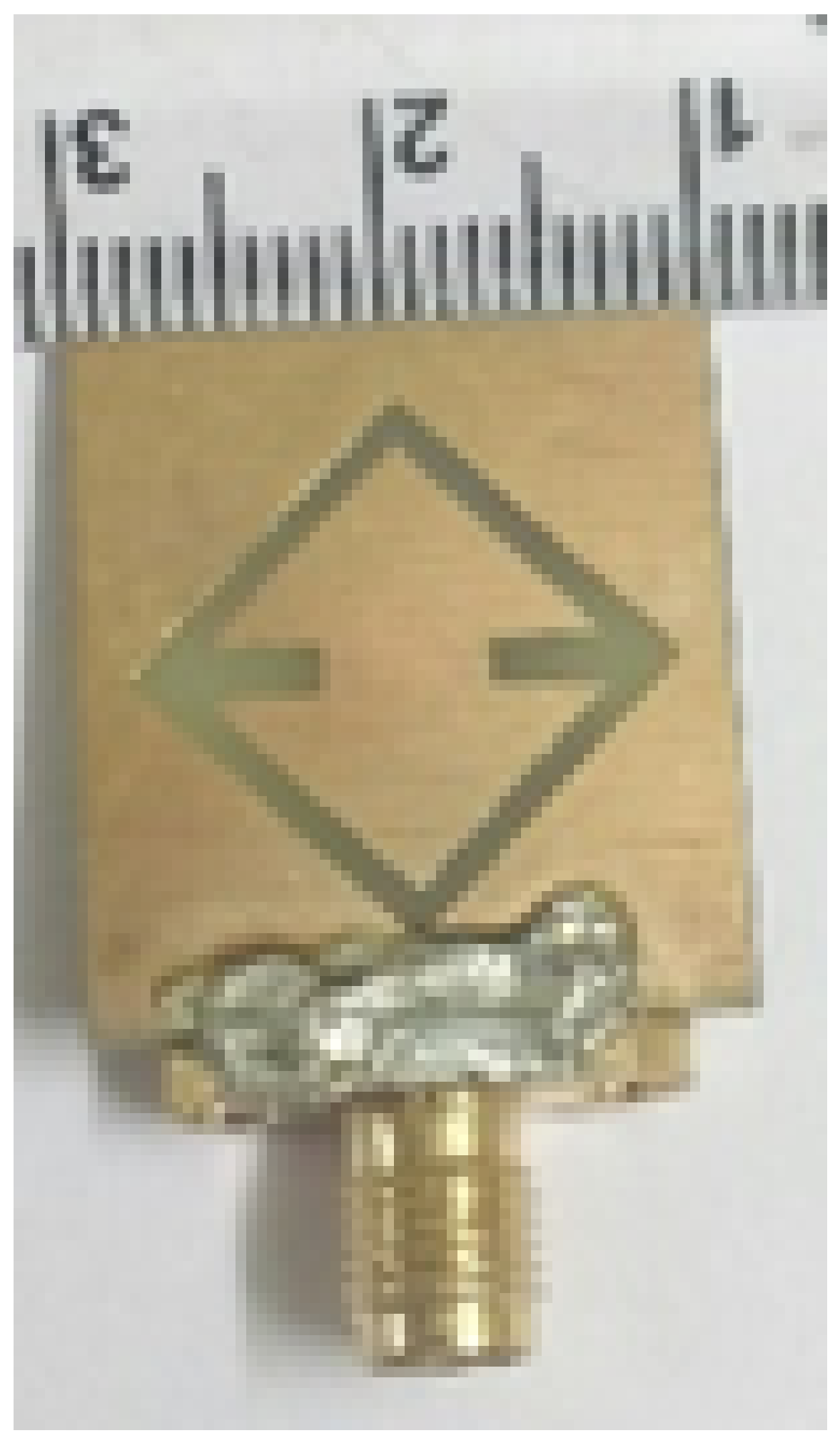




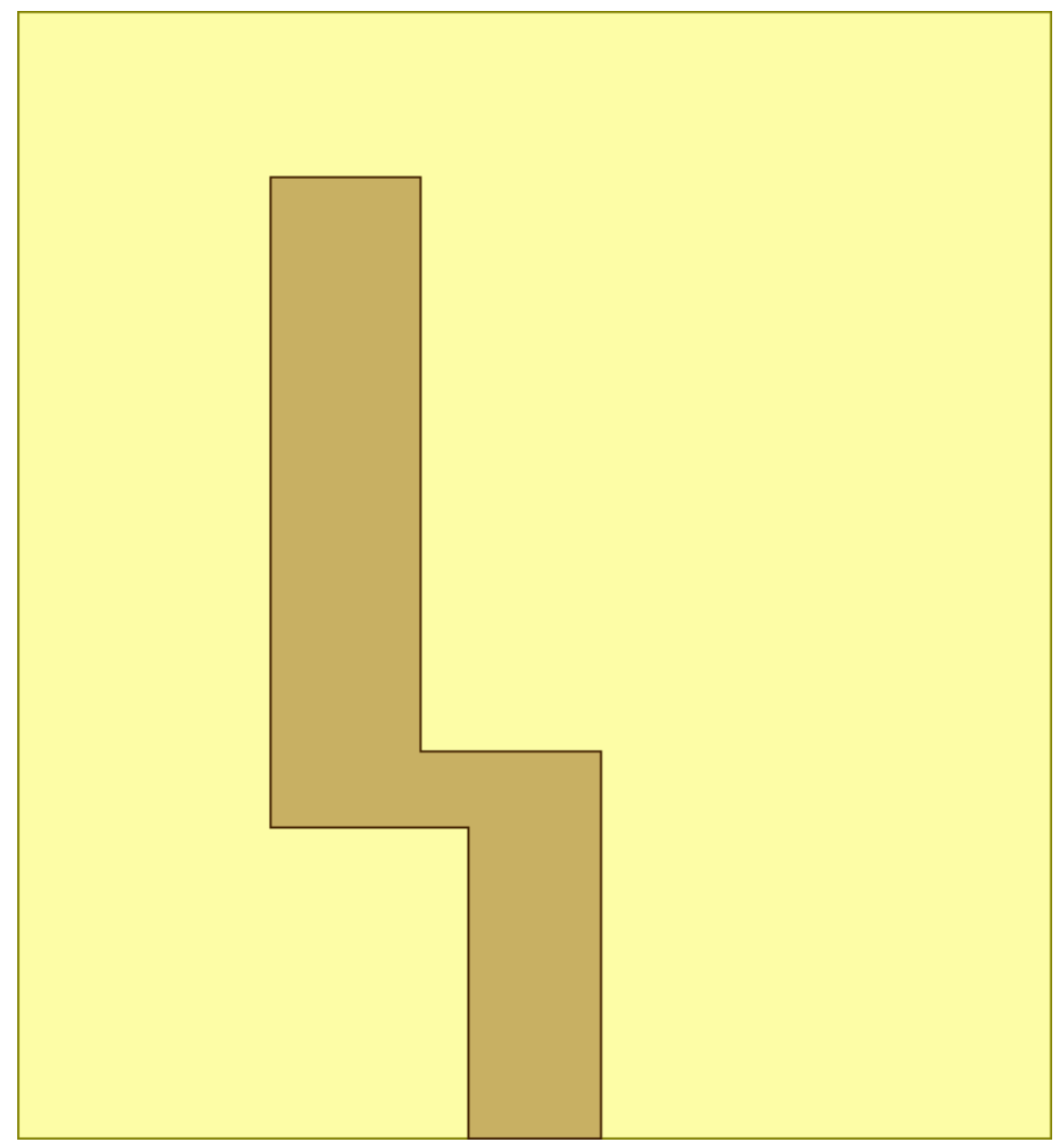




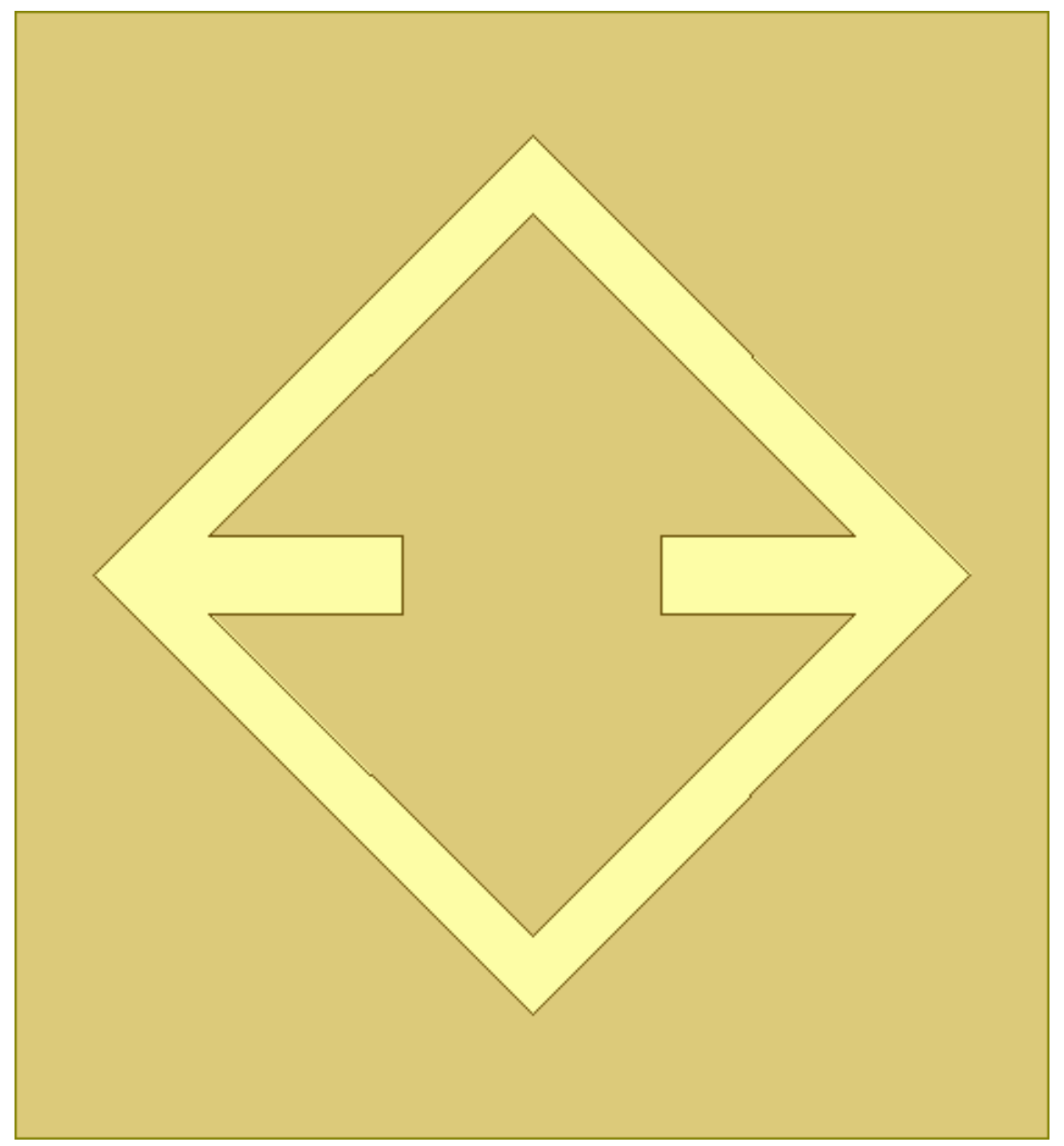




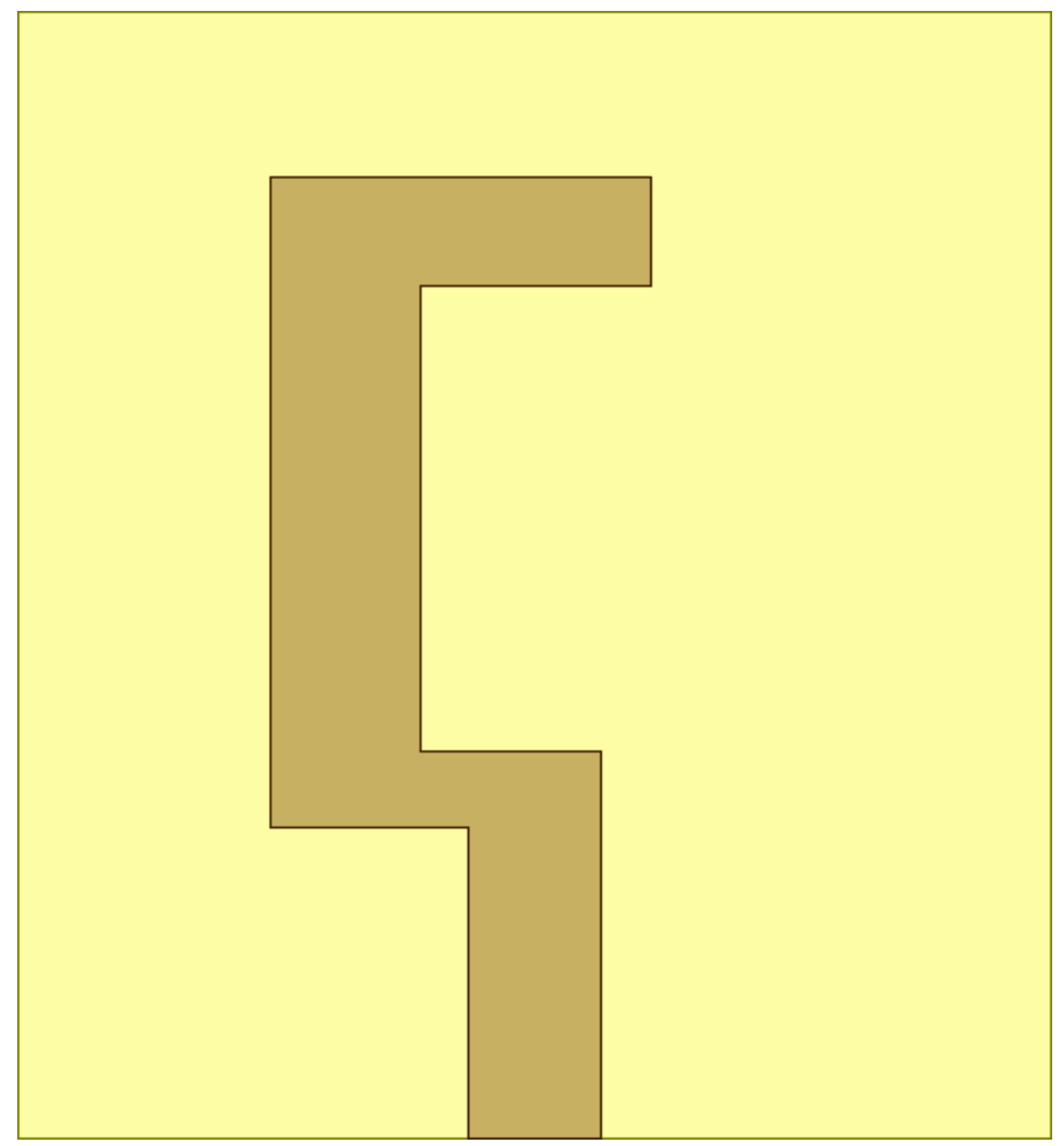




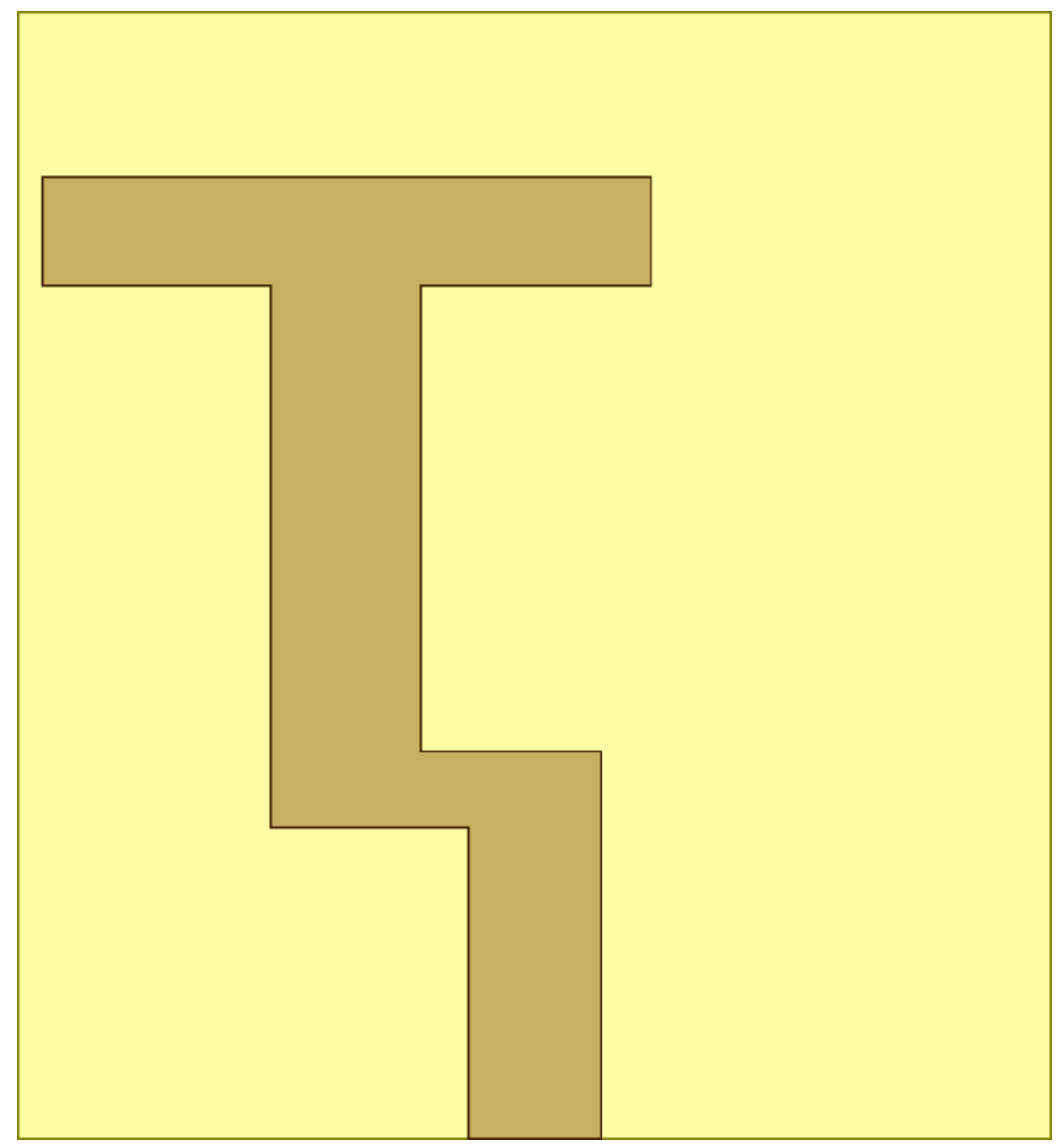



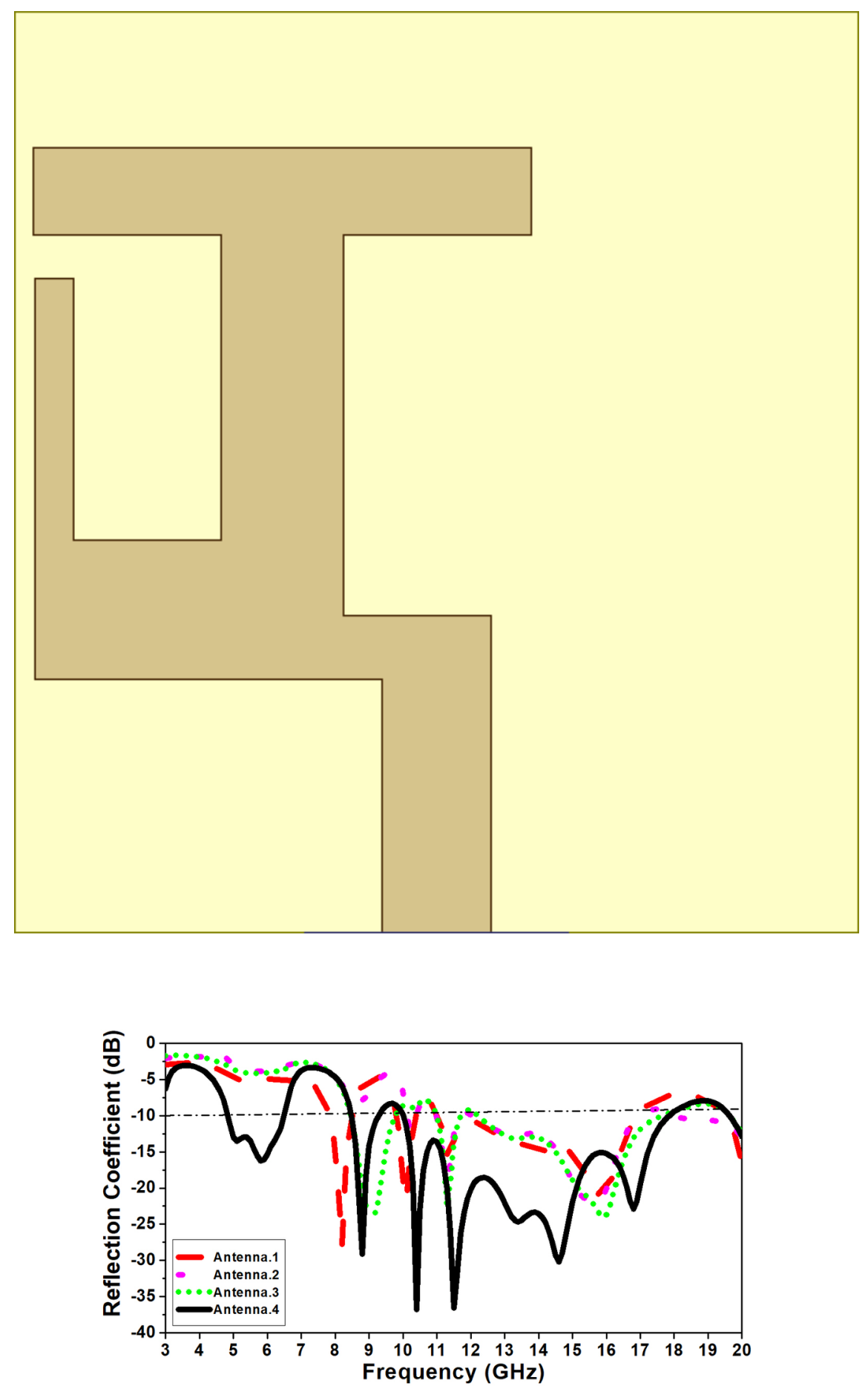

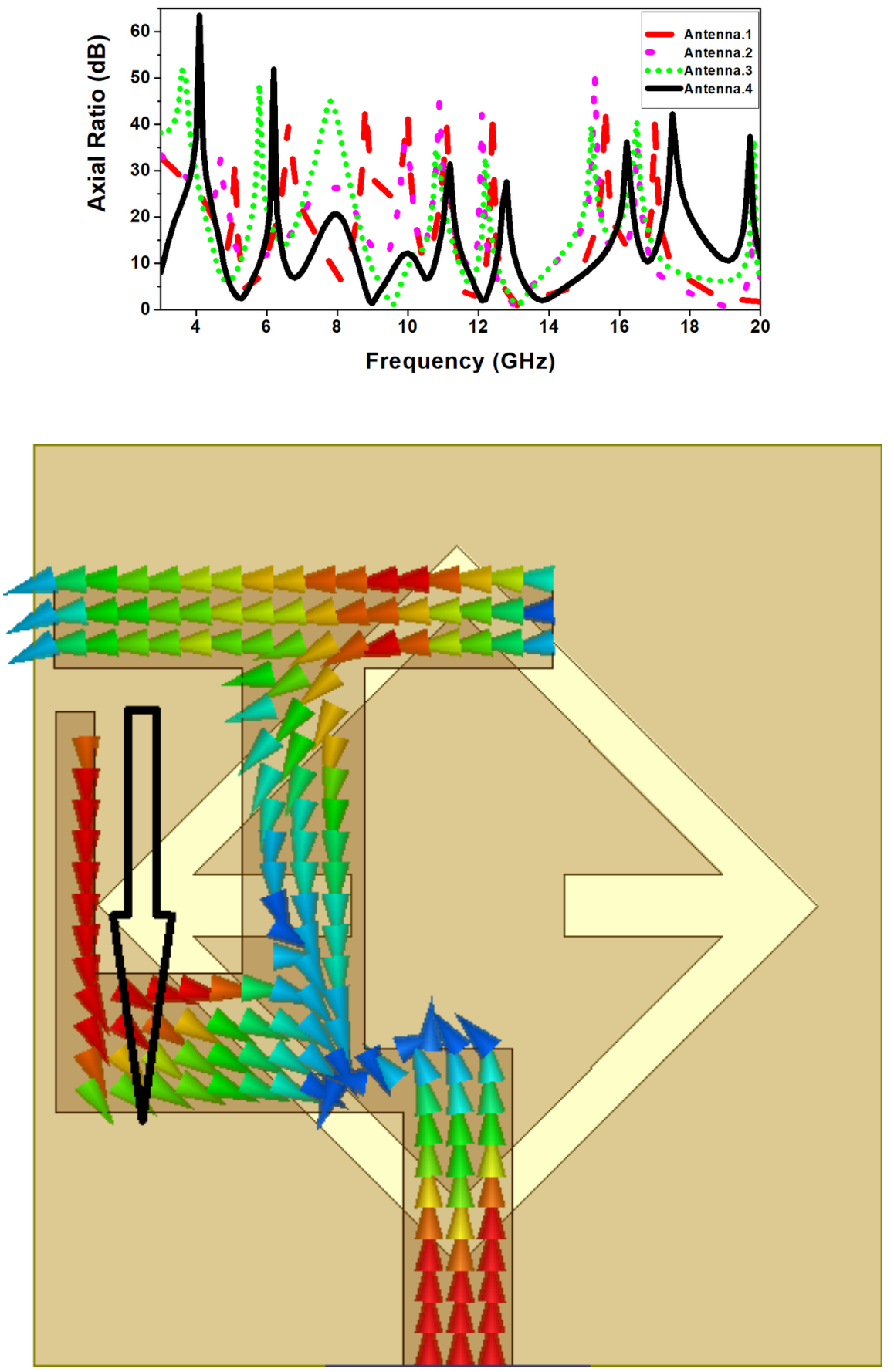


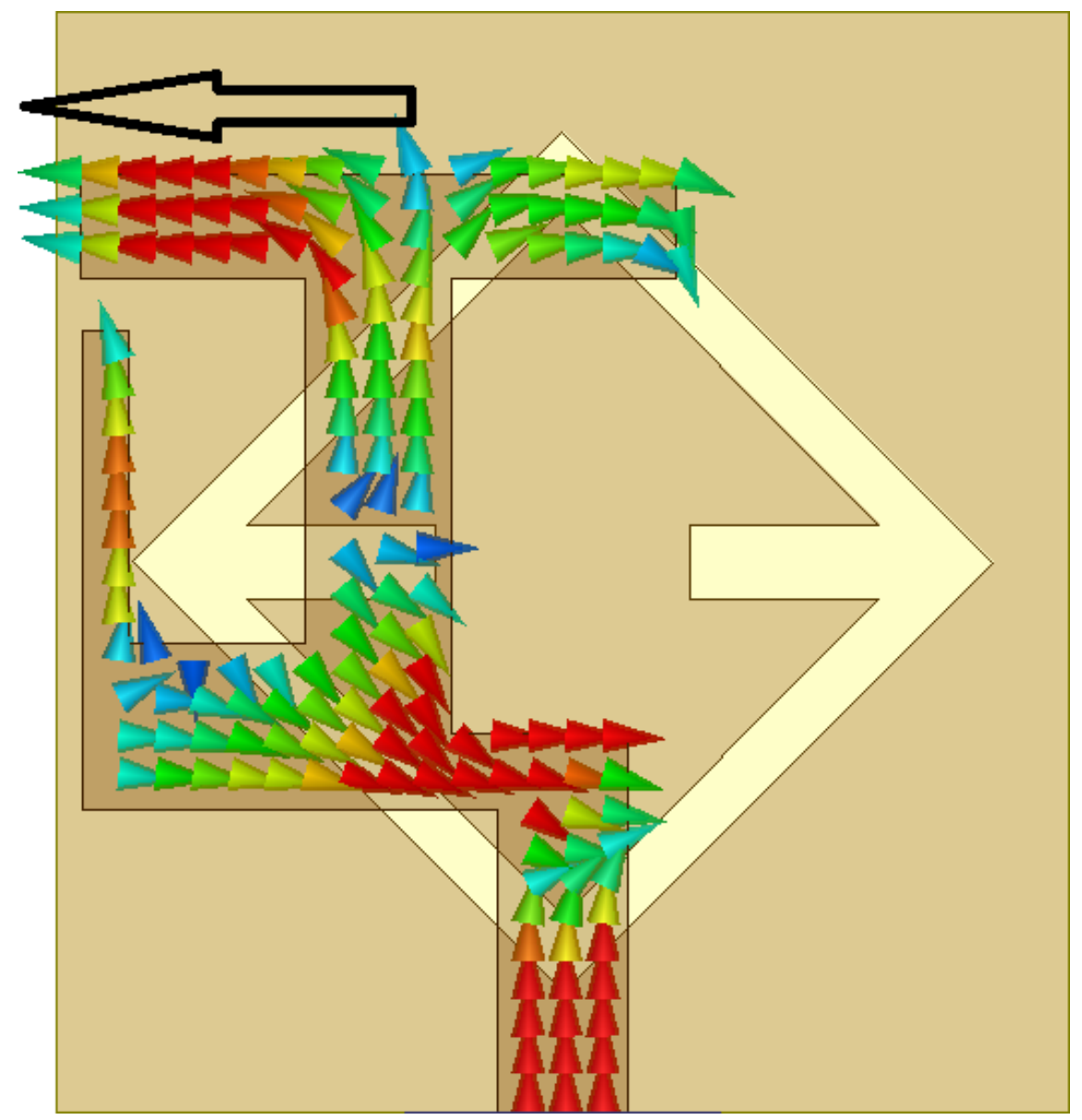




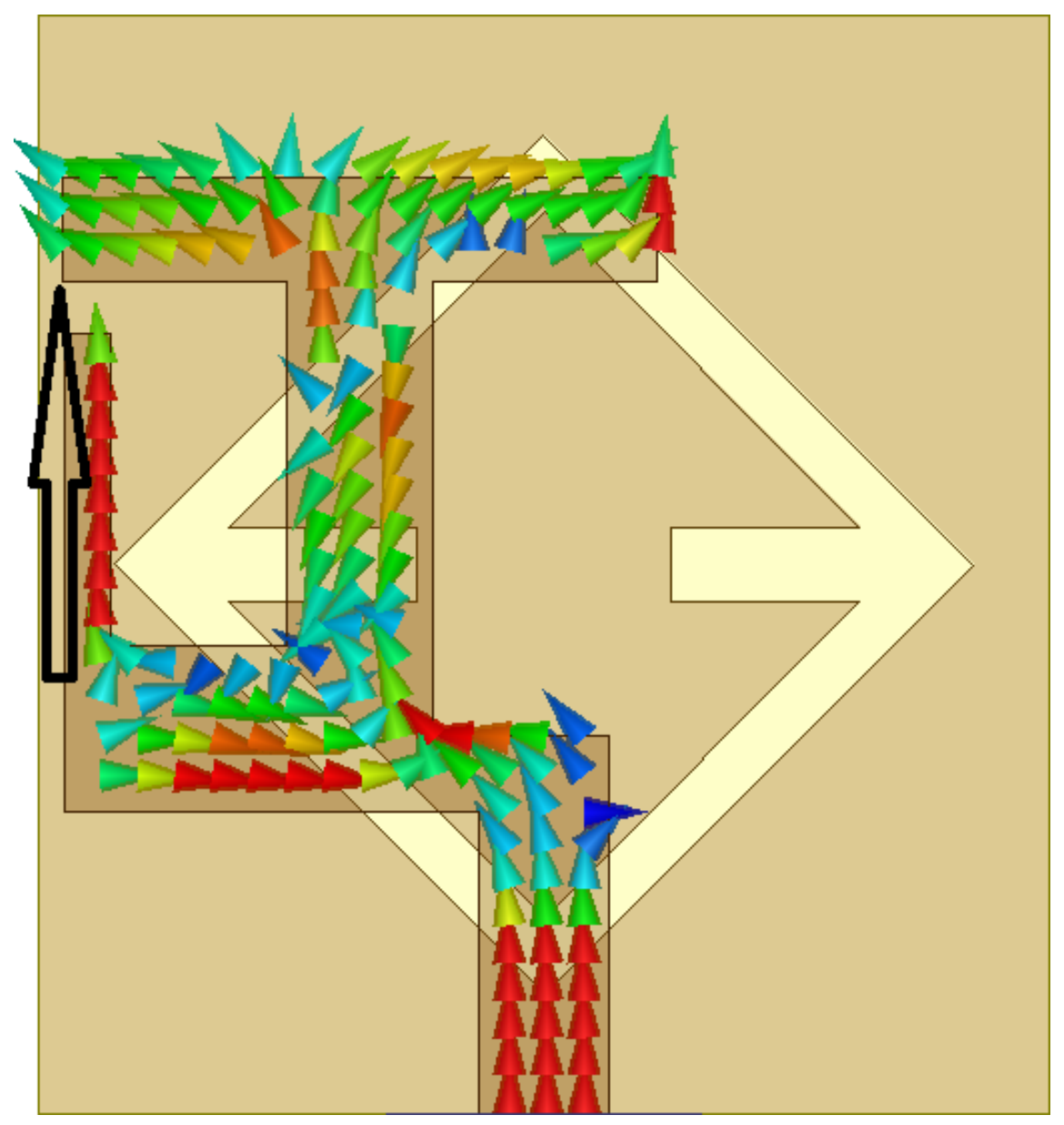




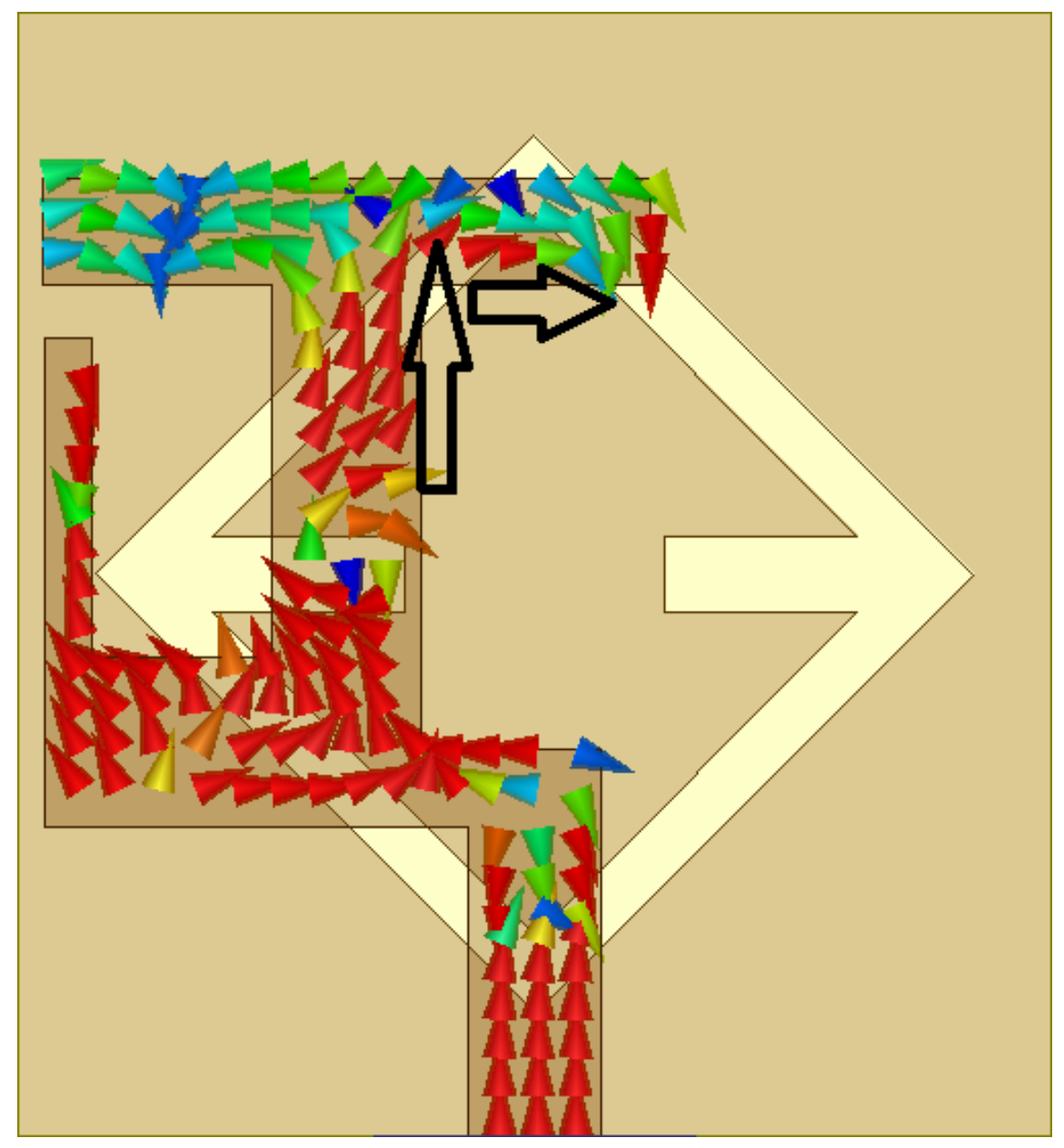




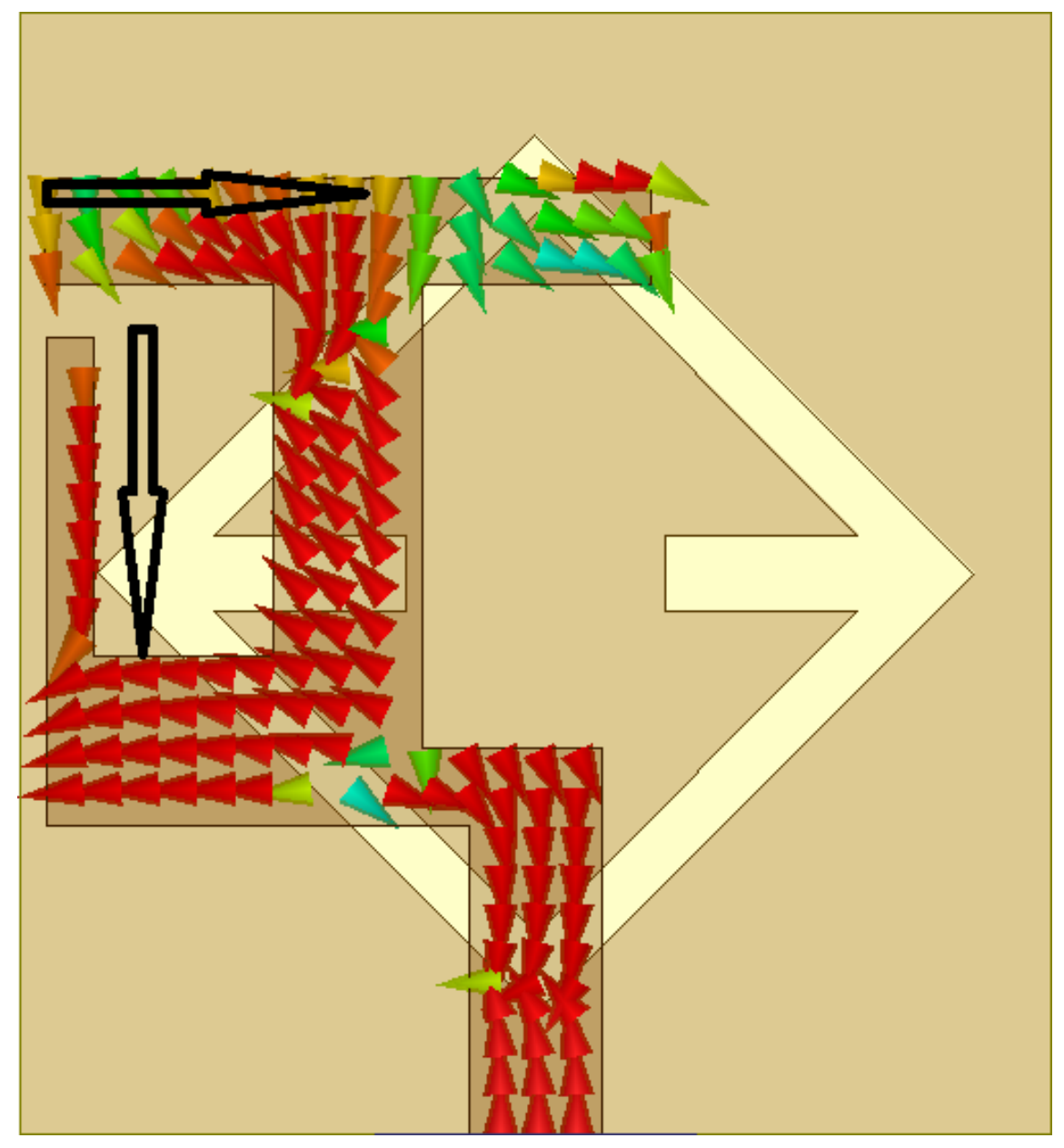




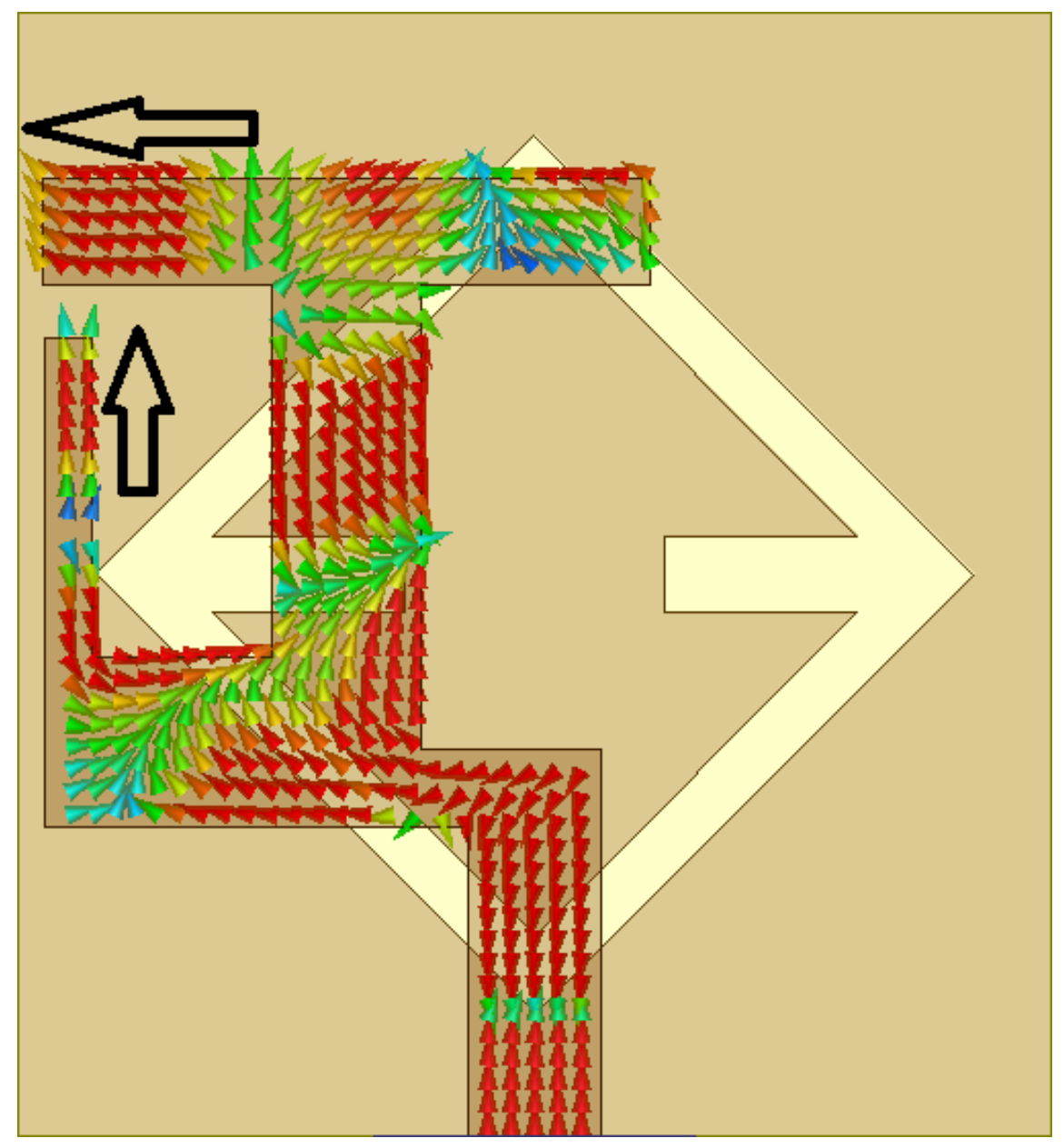




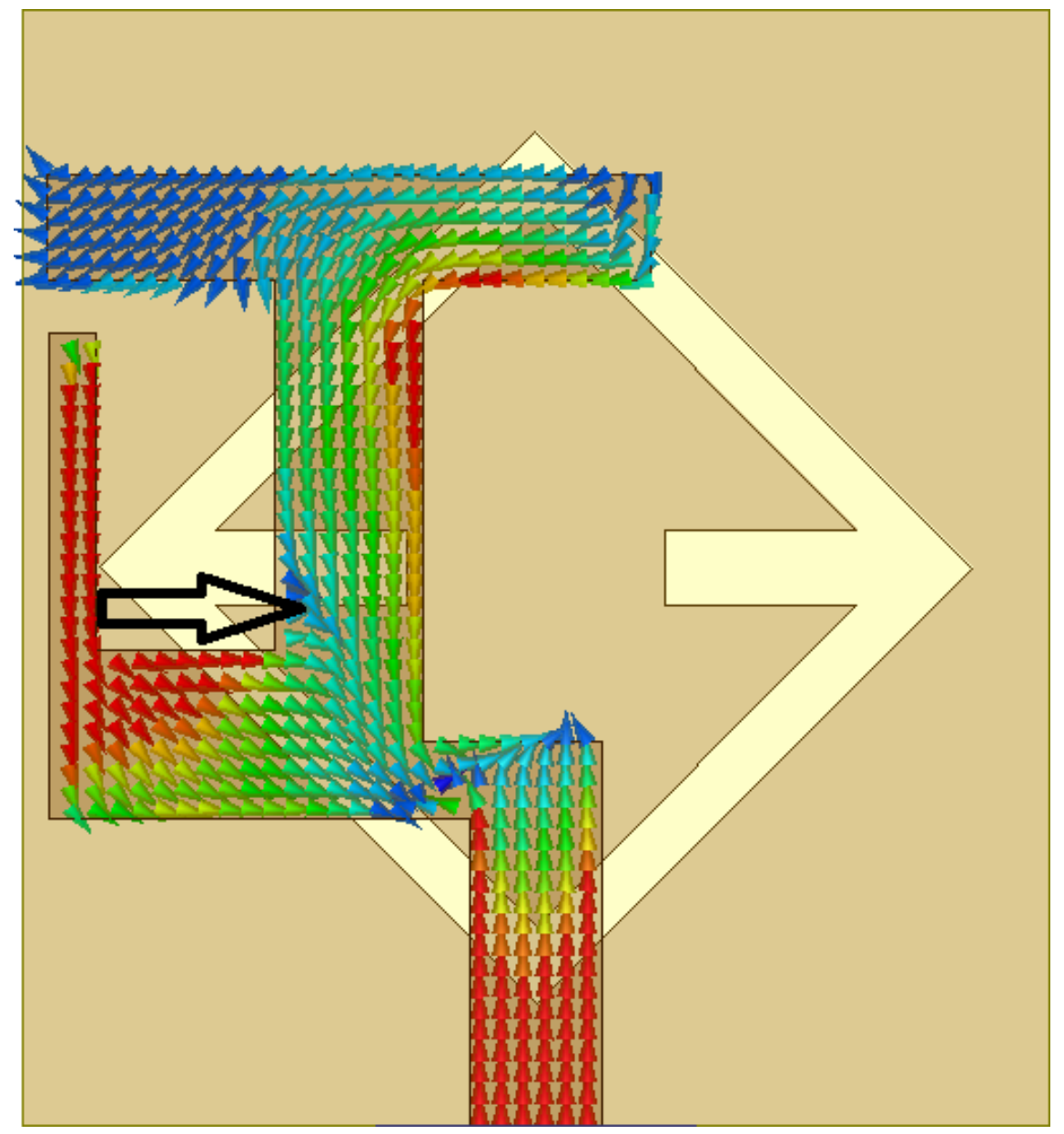




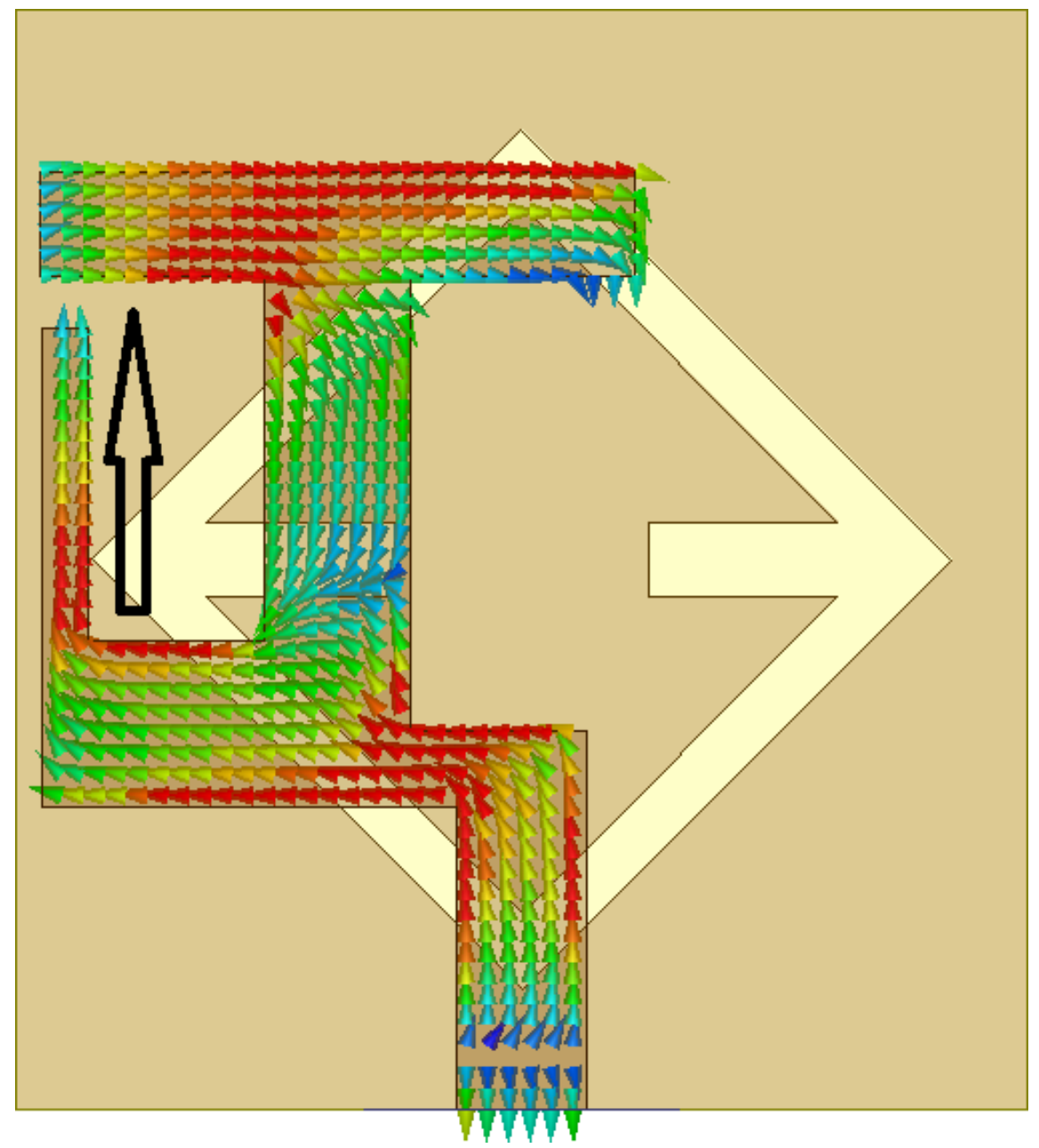




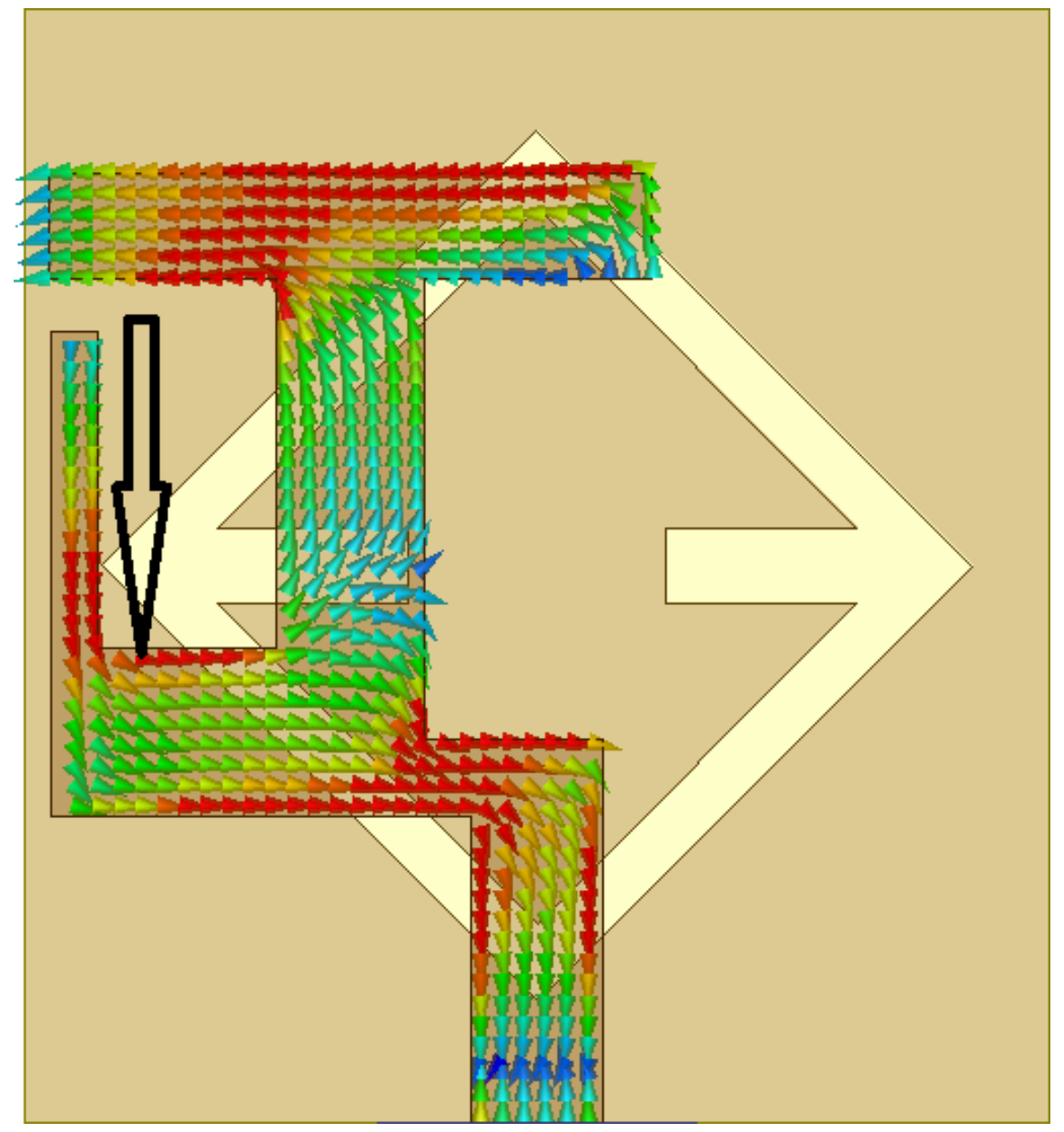




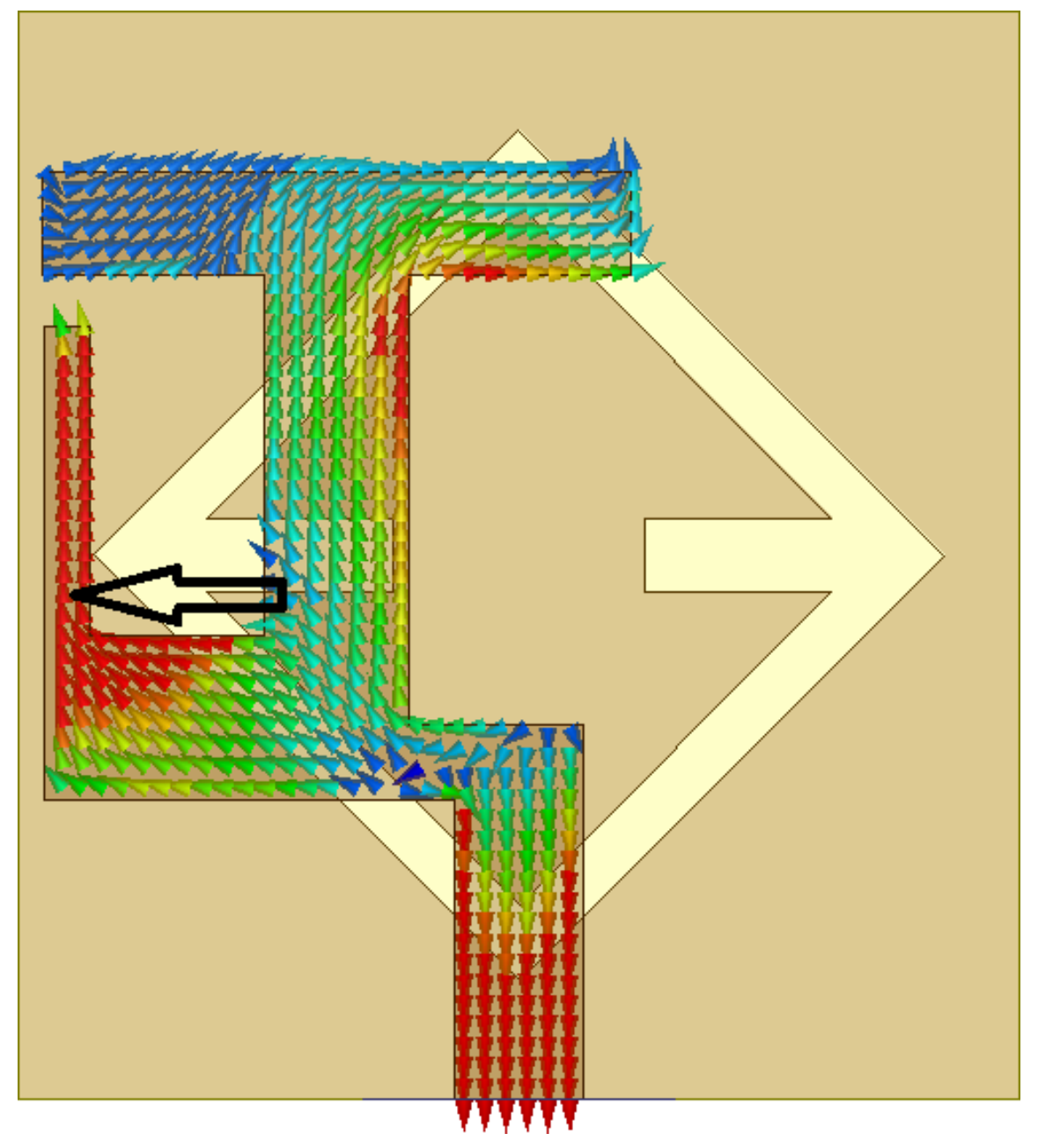




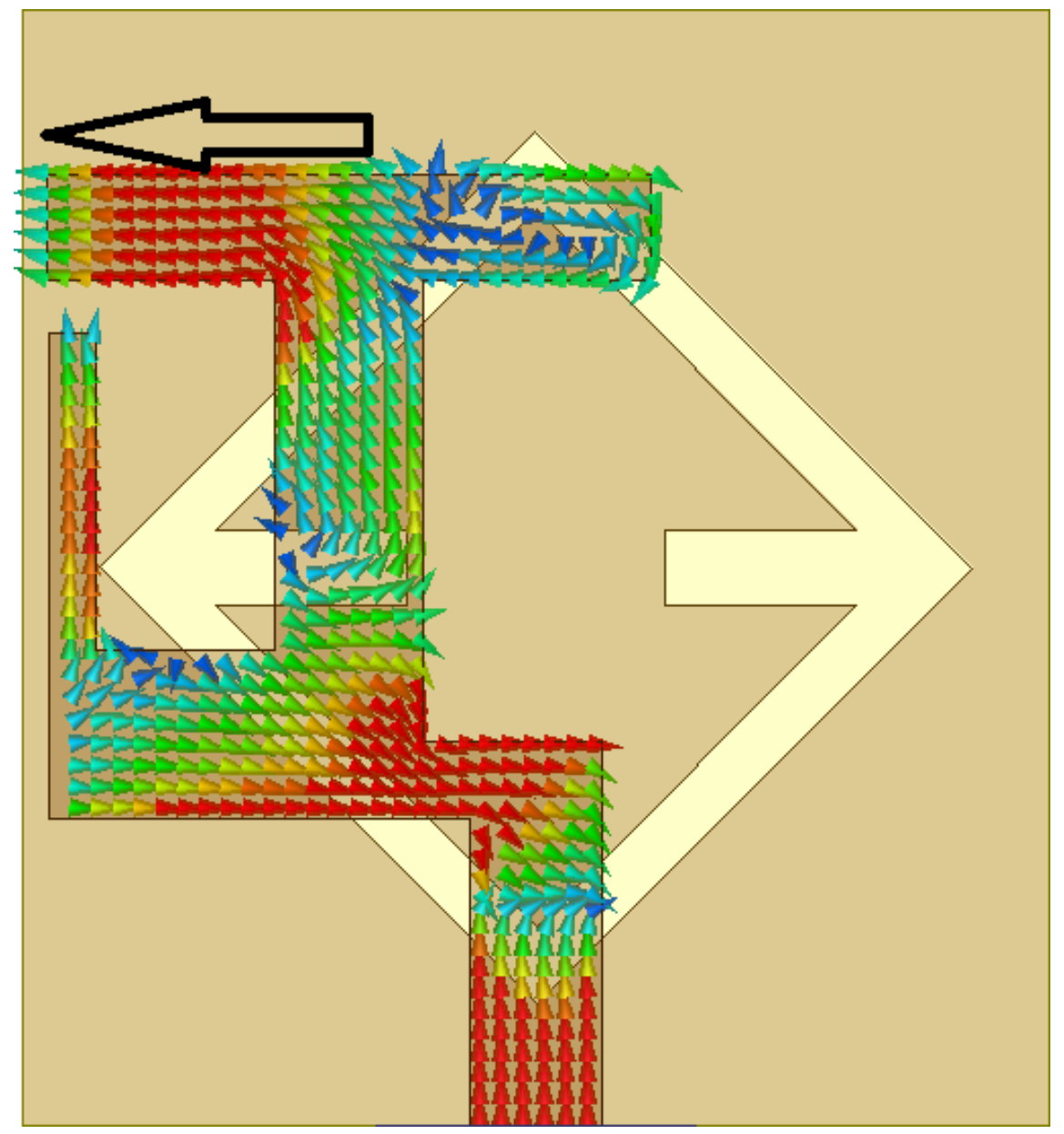




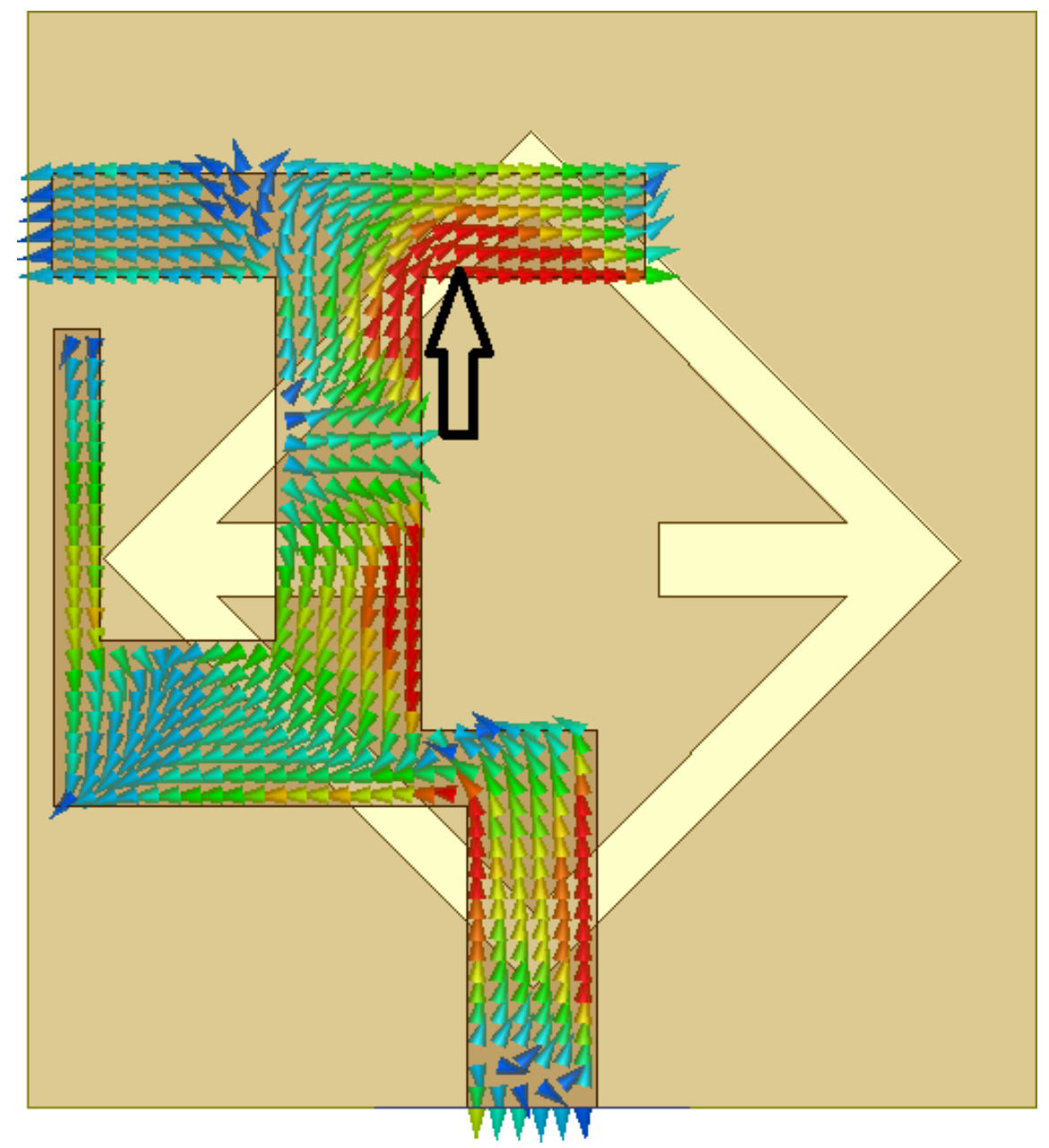




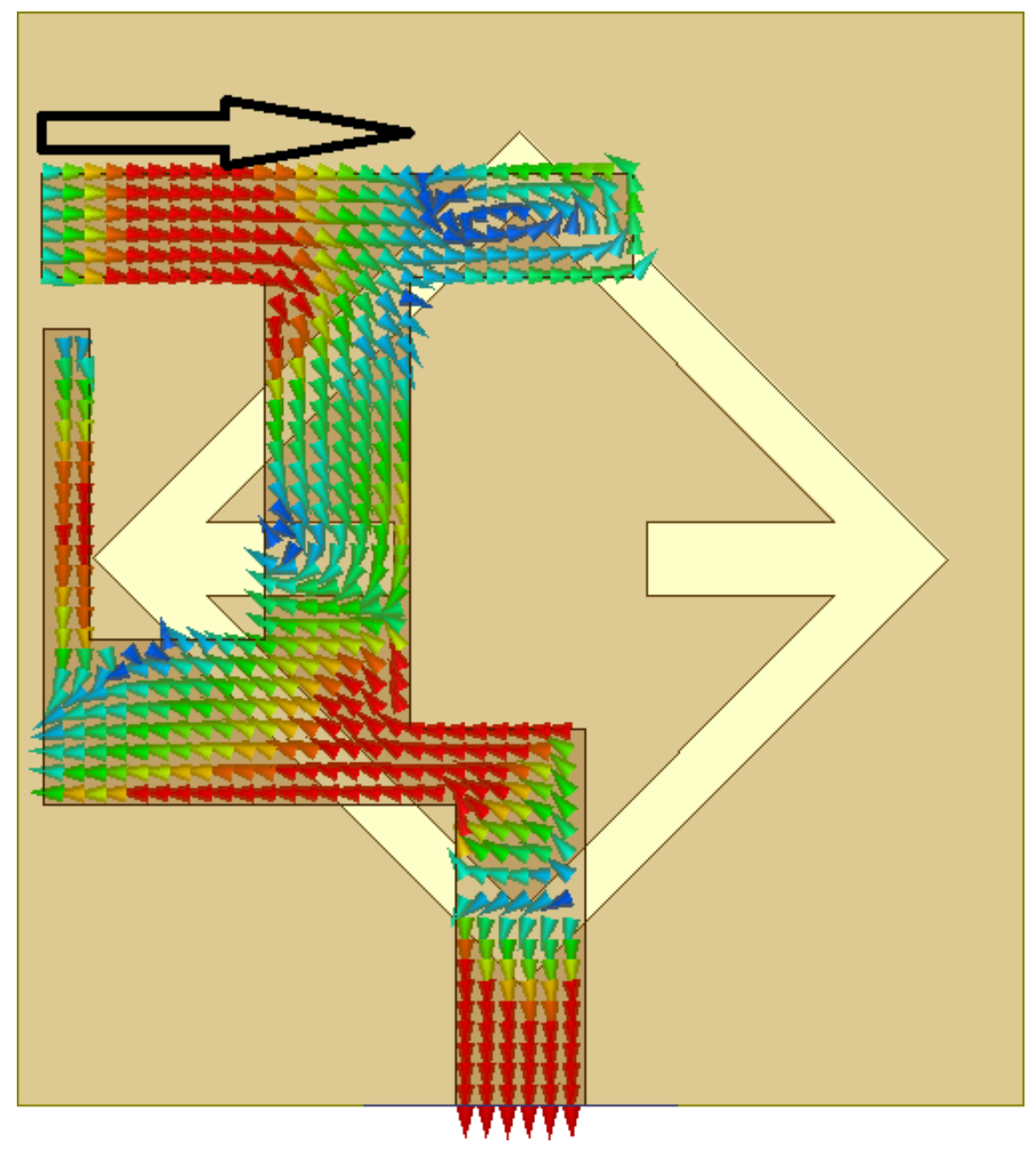




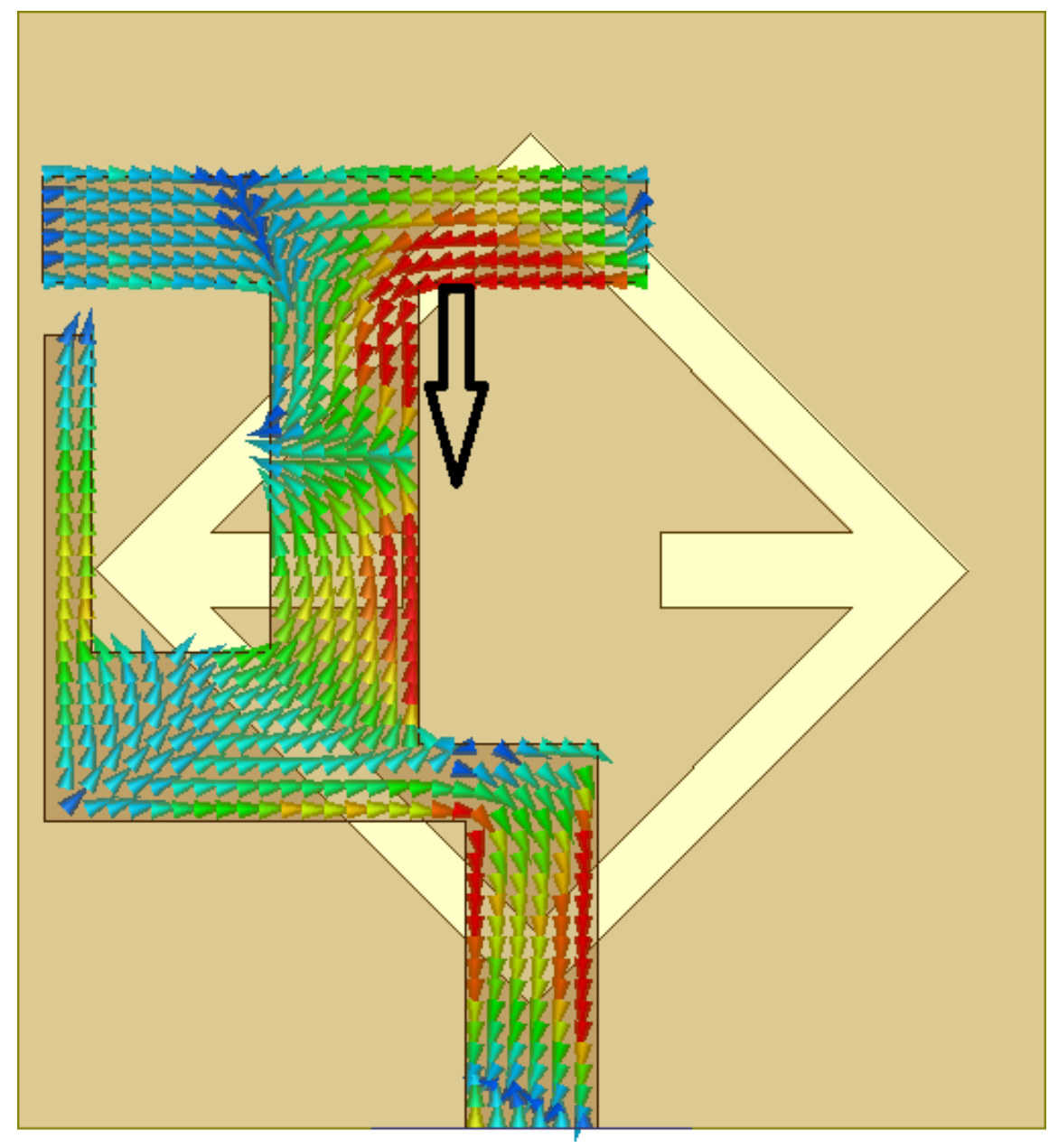




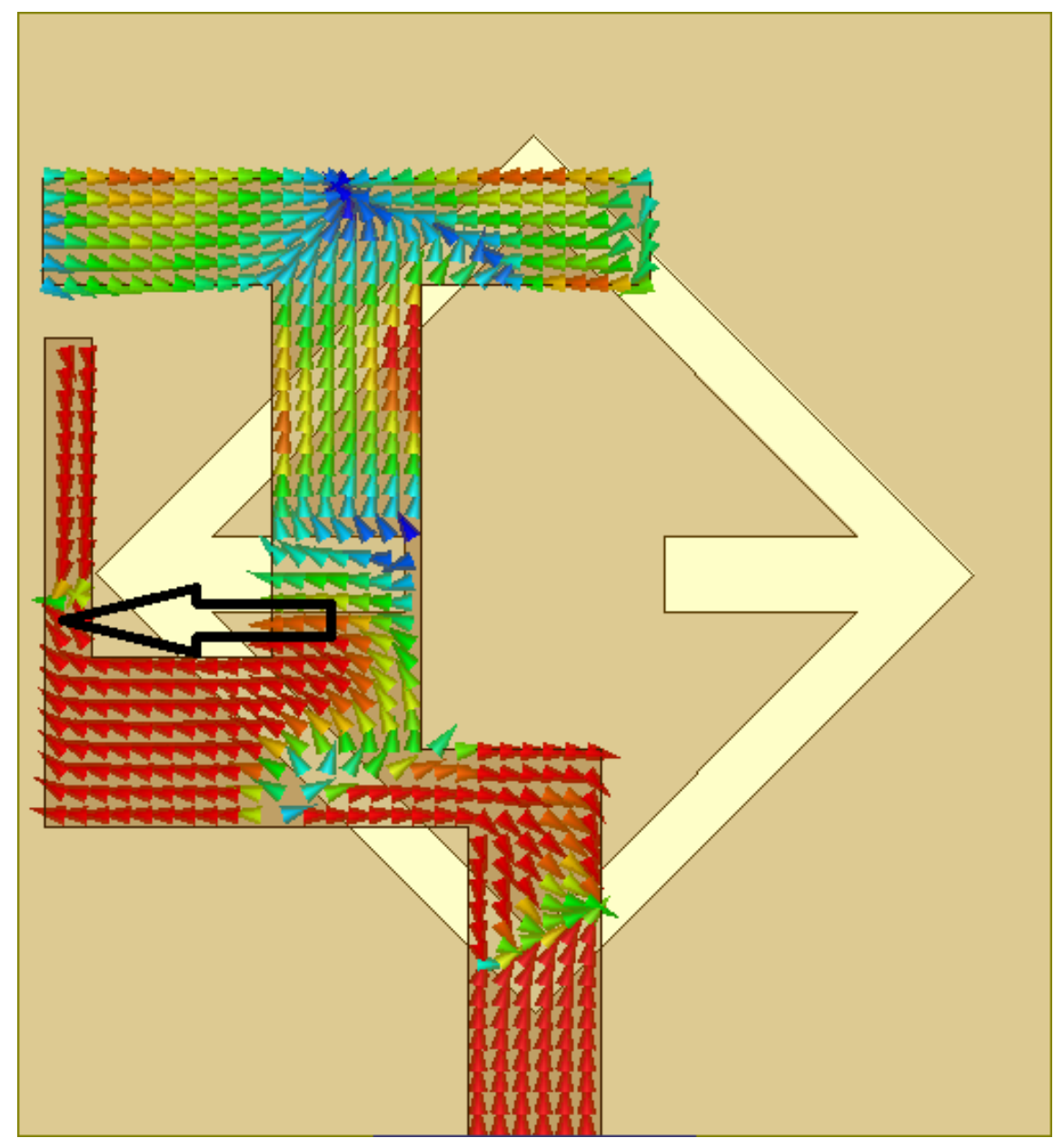




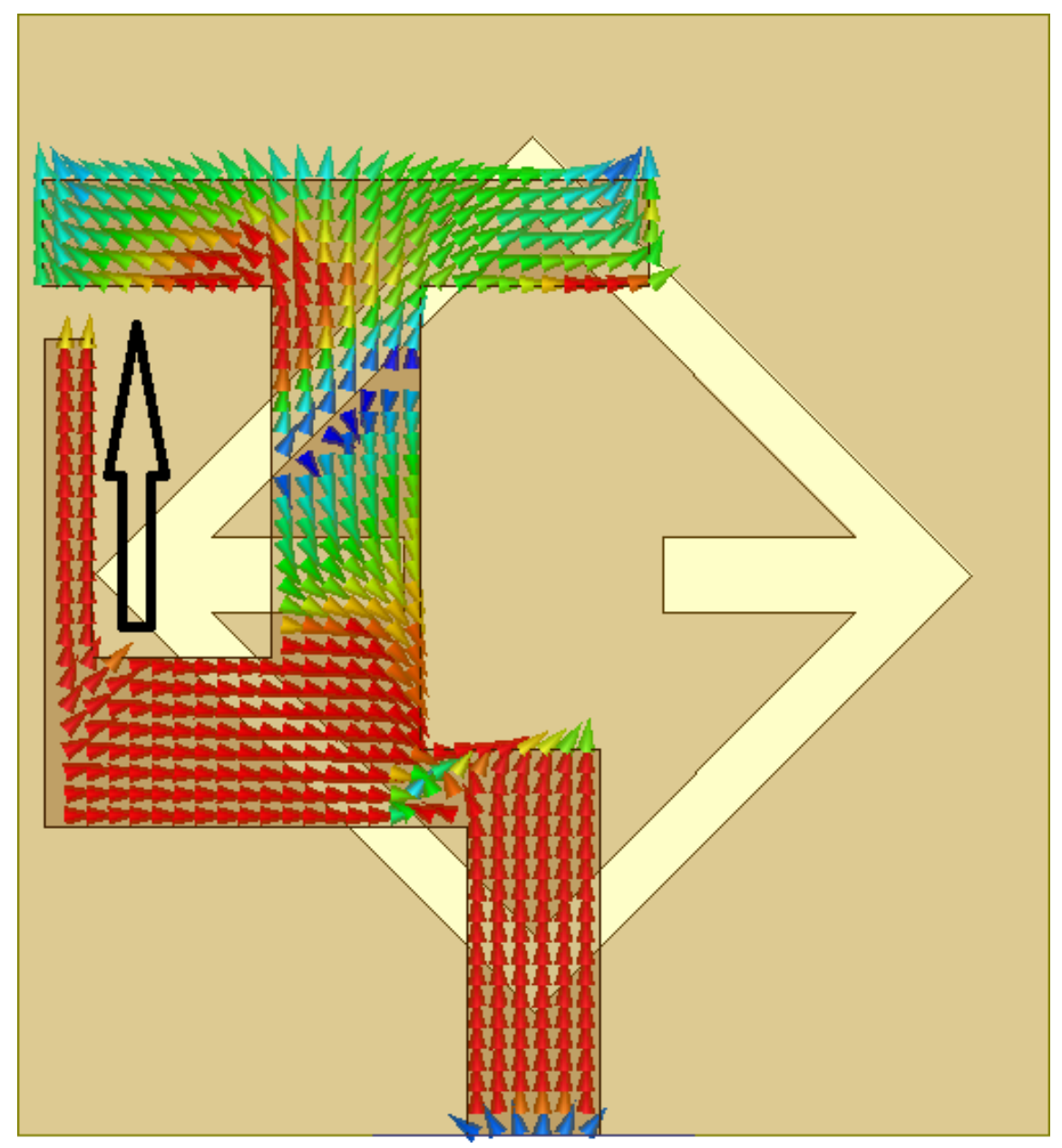




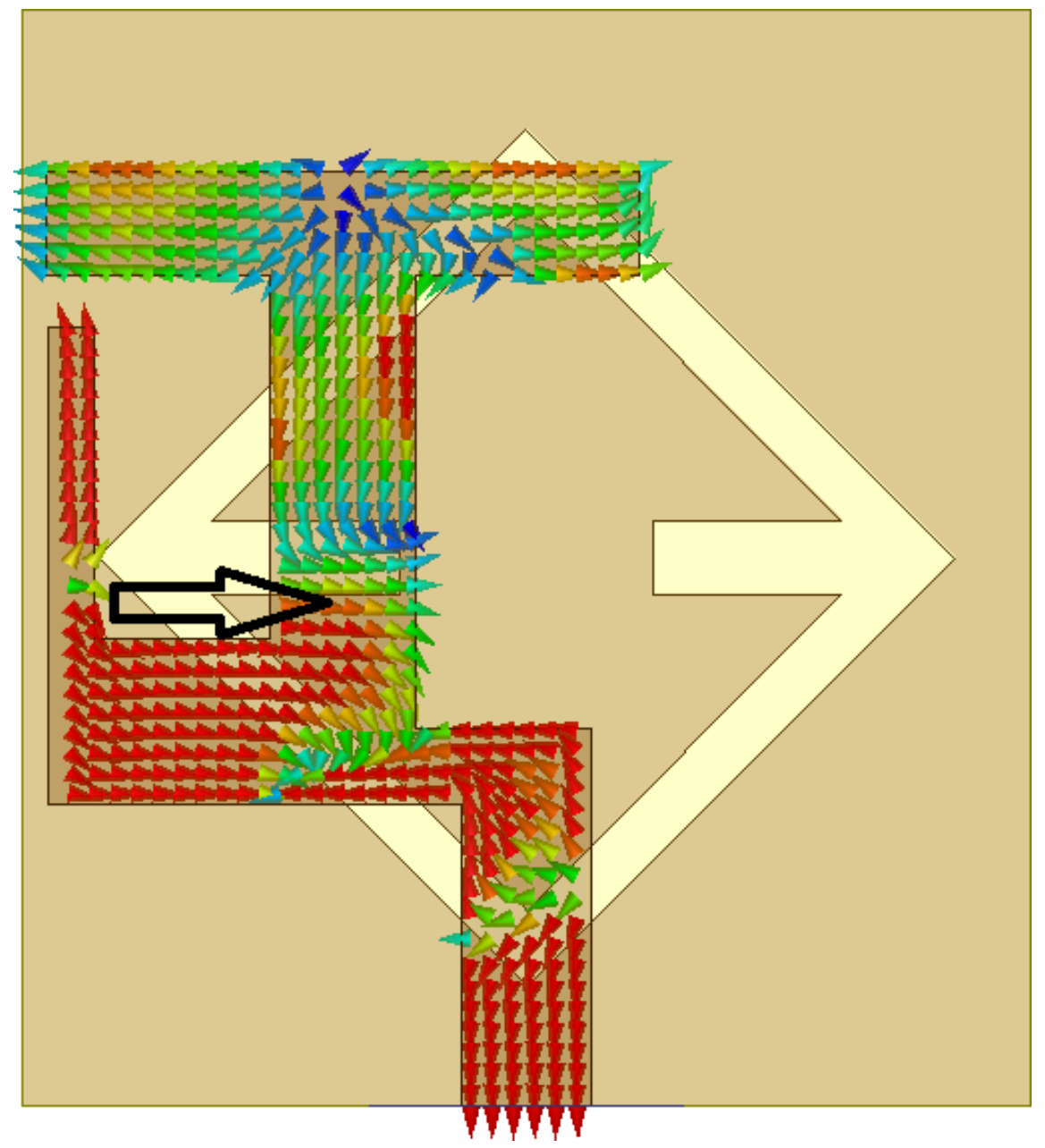




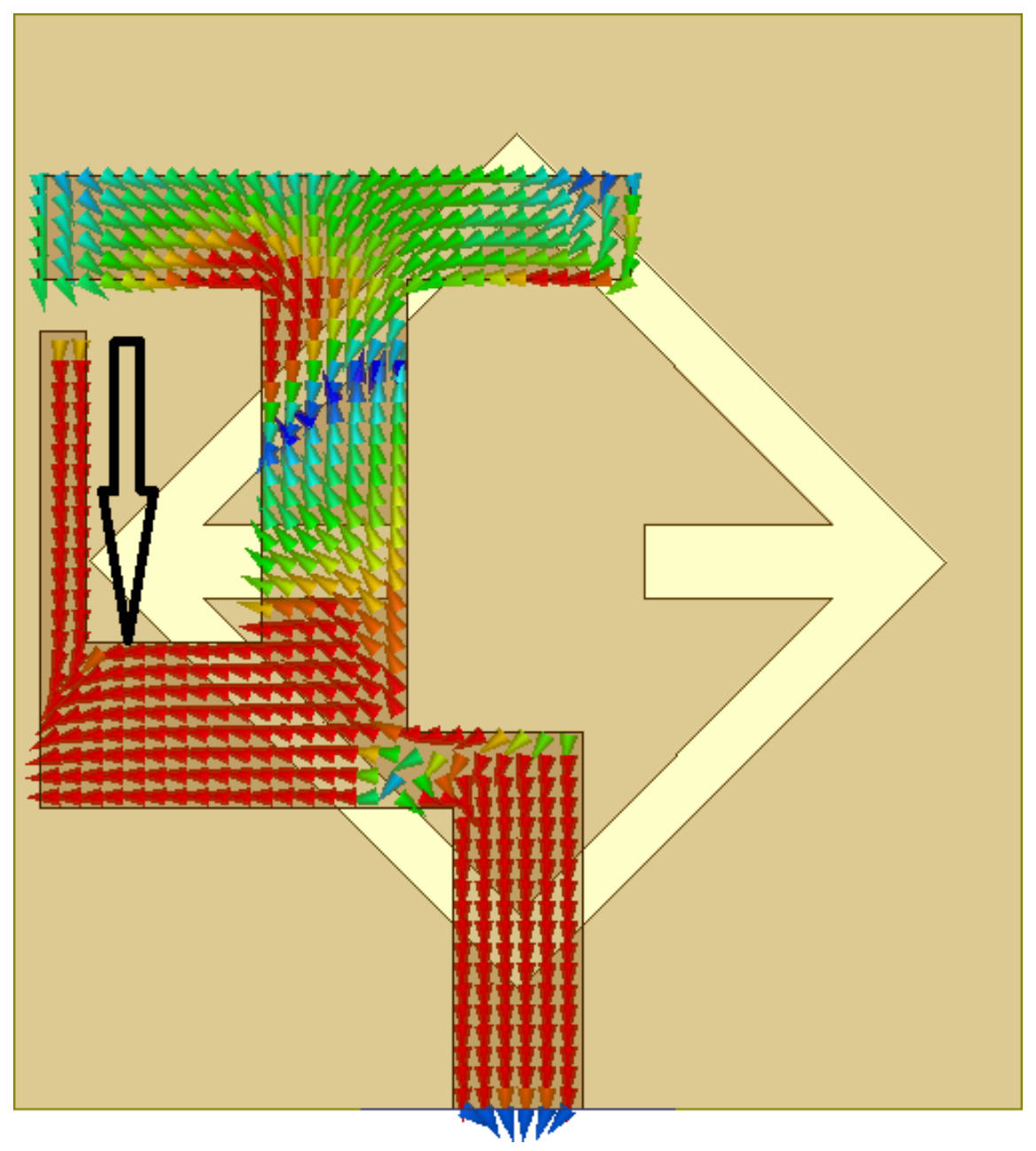




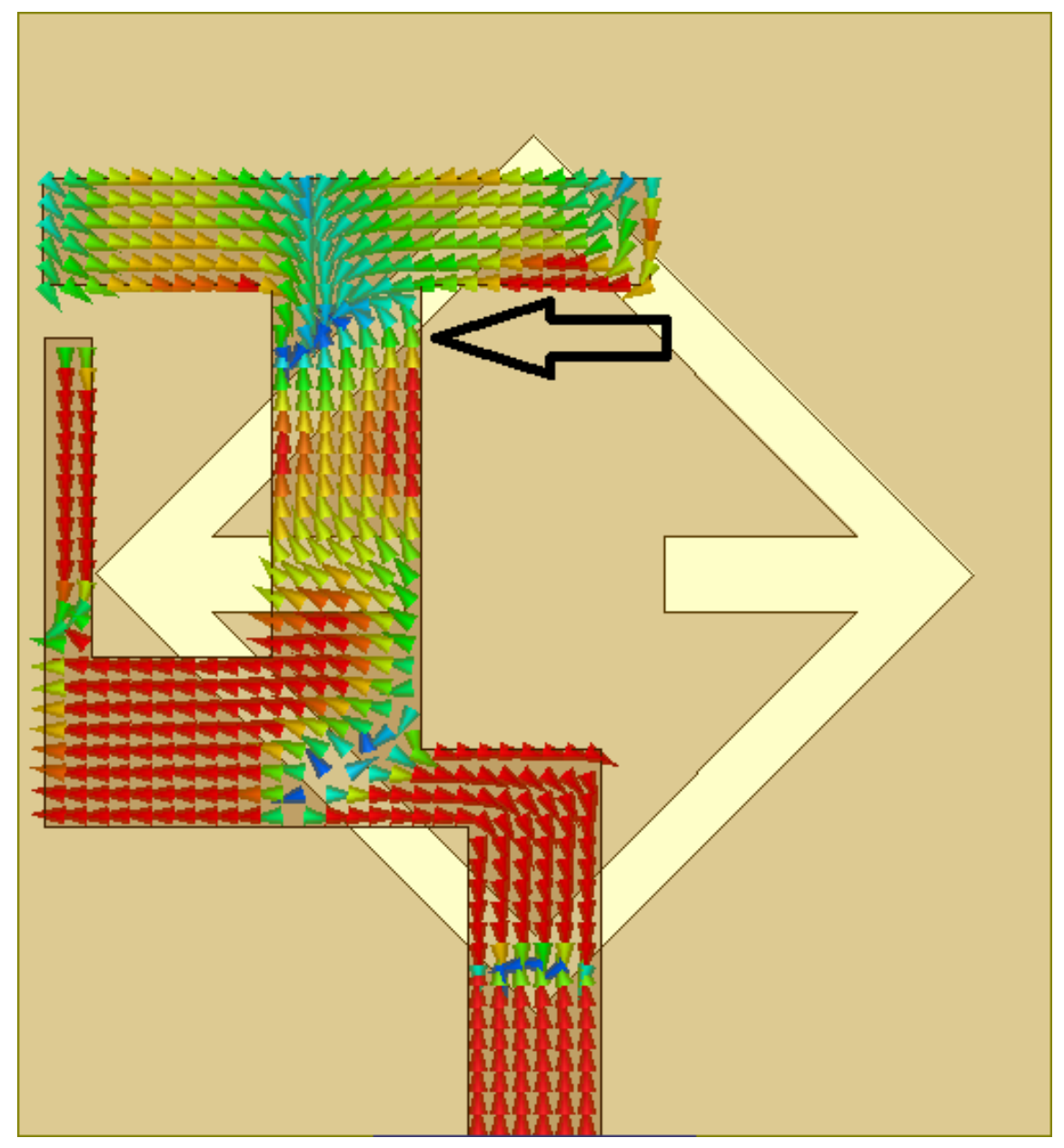




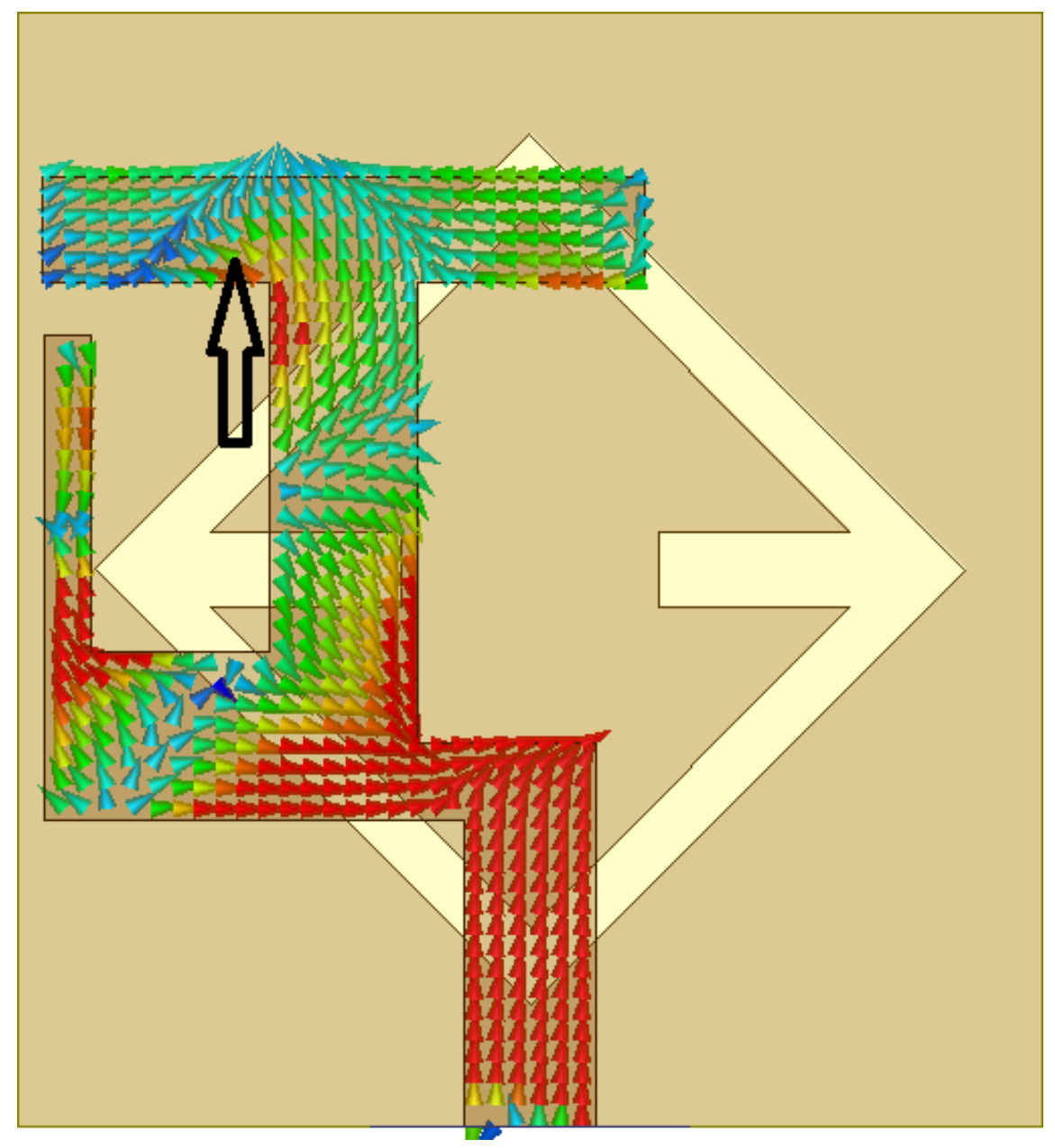




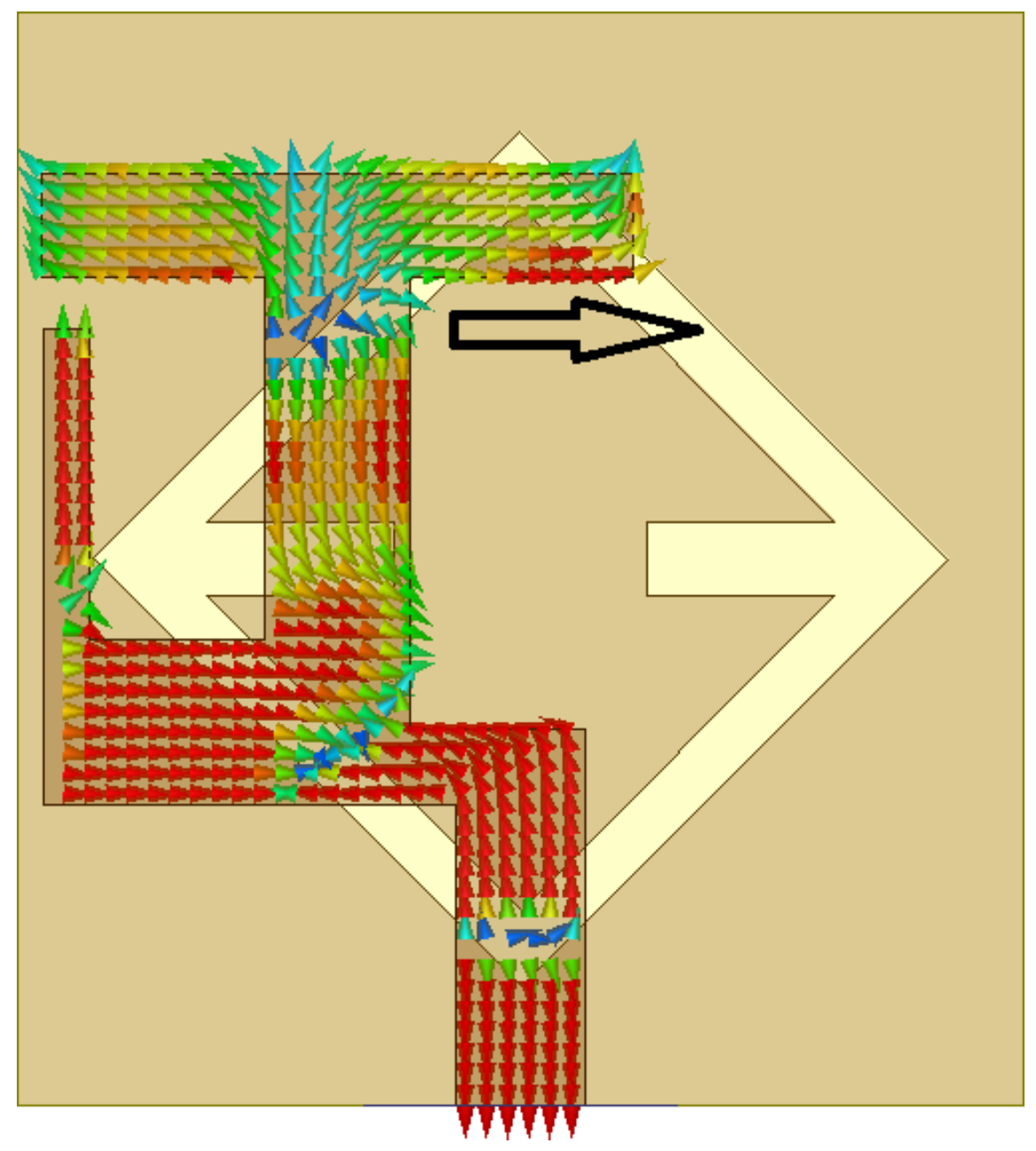




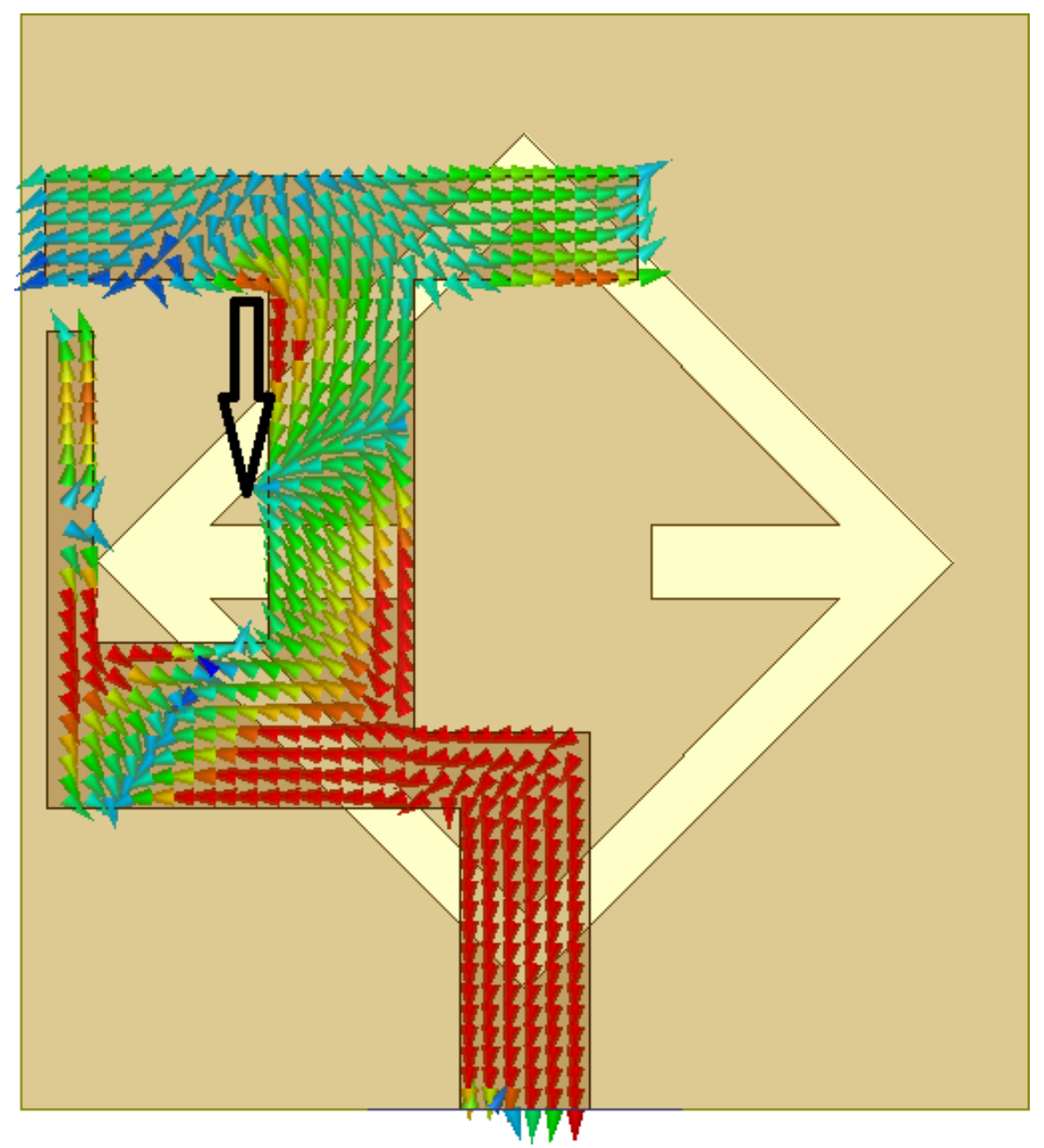

\section{Hosted file}

10-S+M.jpg available at https://authorea.com/users/301864/articles/432368-a-novel-quad-bandcircularly-polarized-planar-slot-antenna-using-triple-strips 

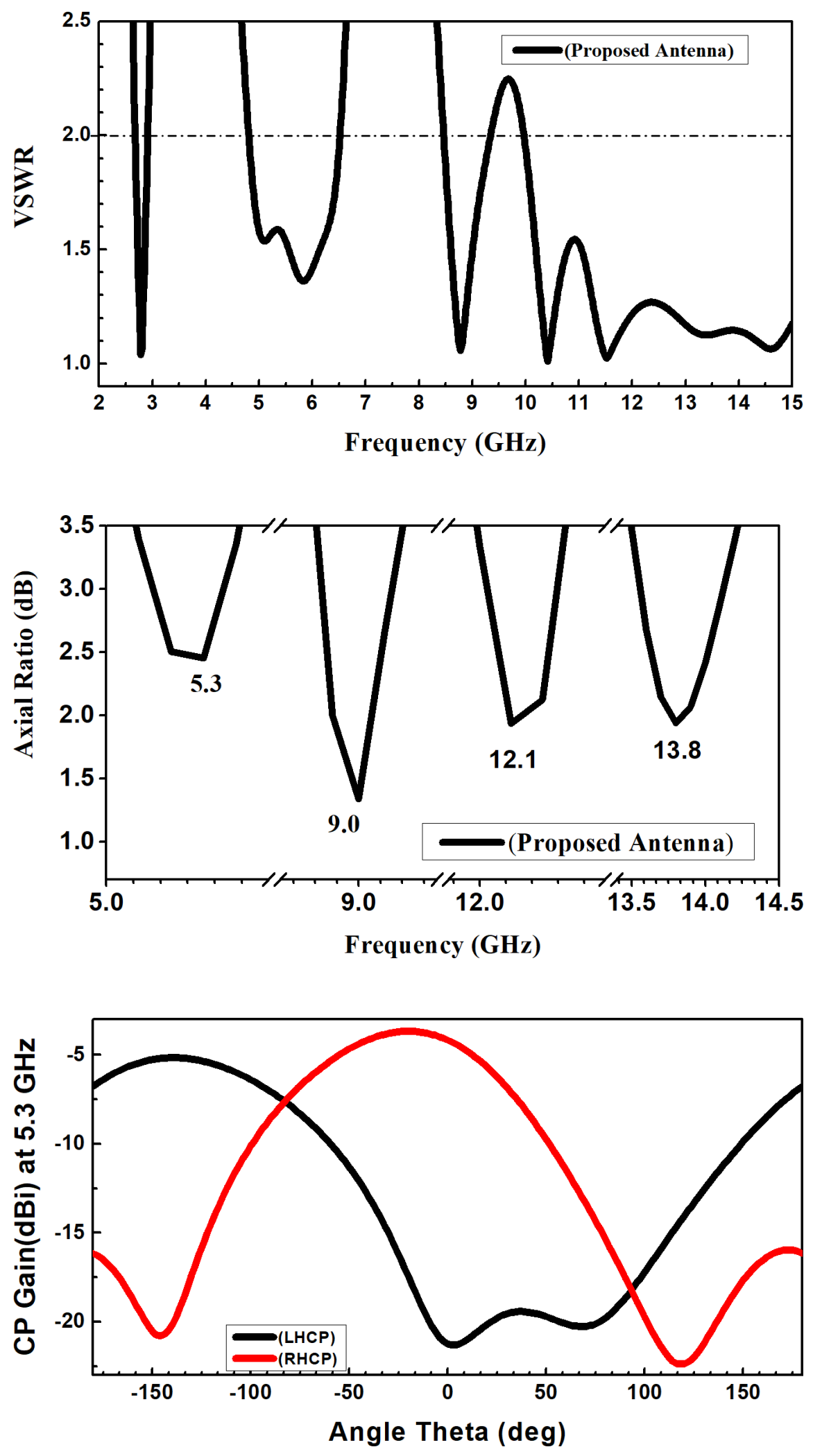

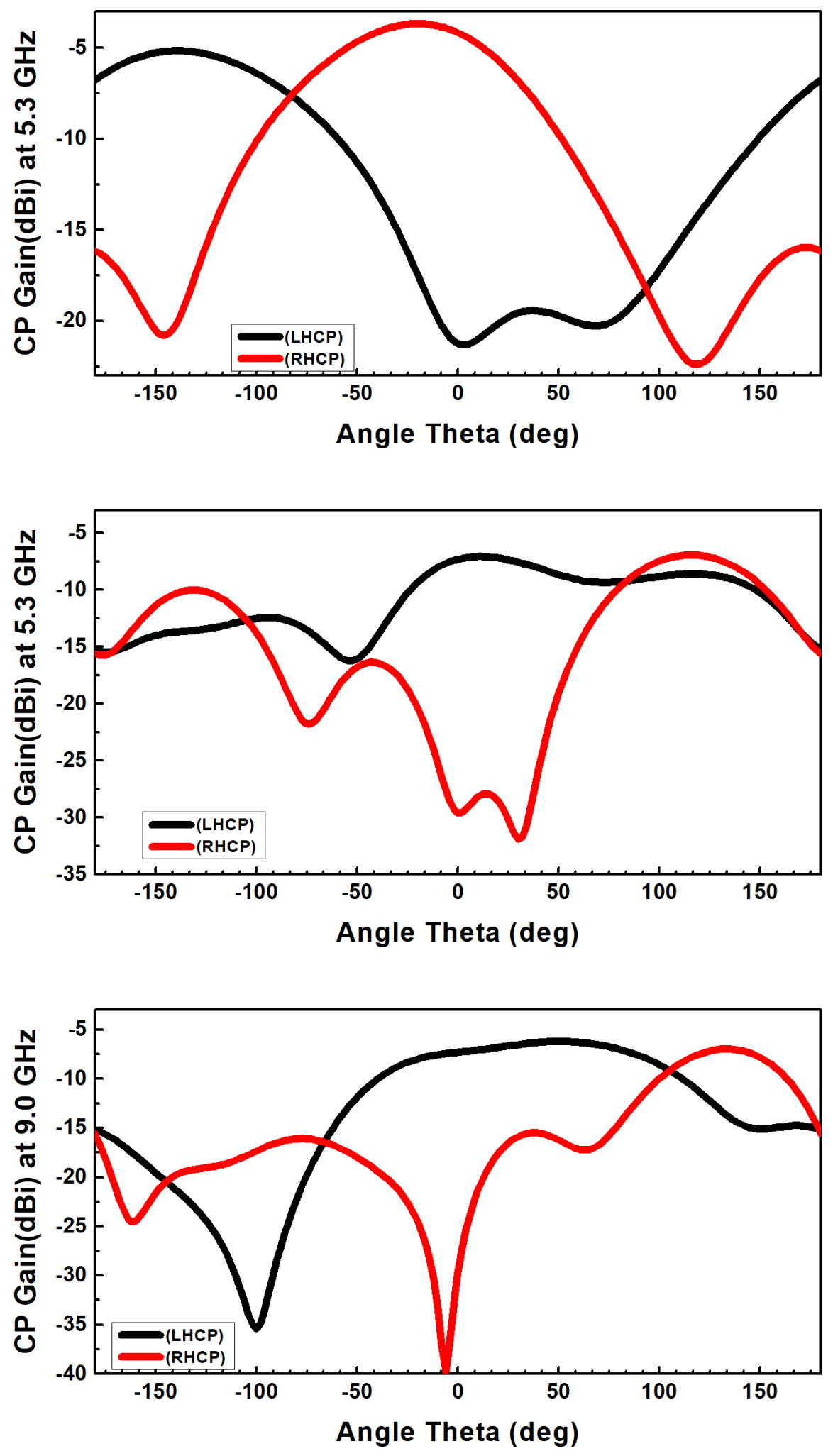

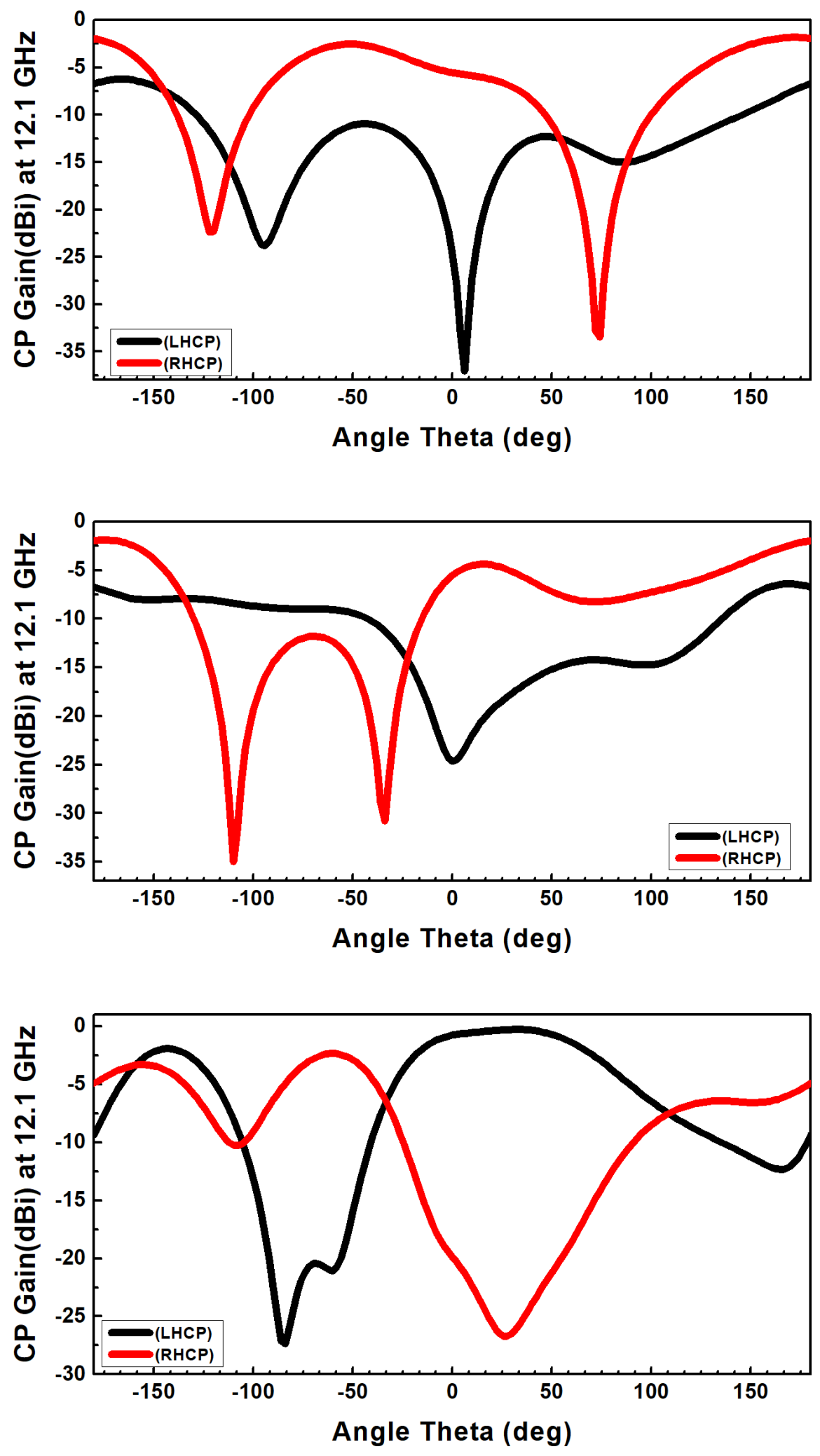

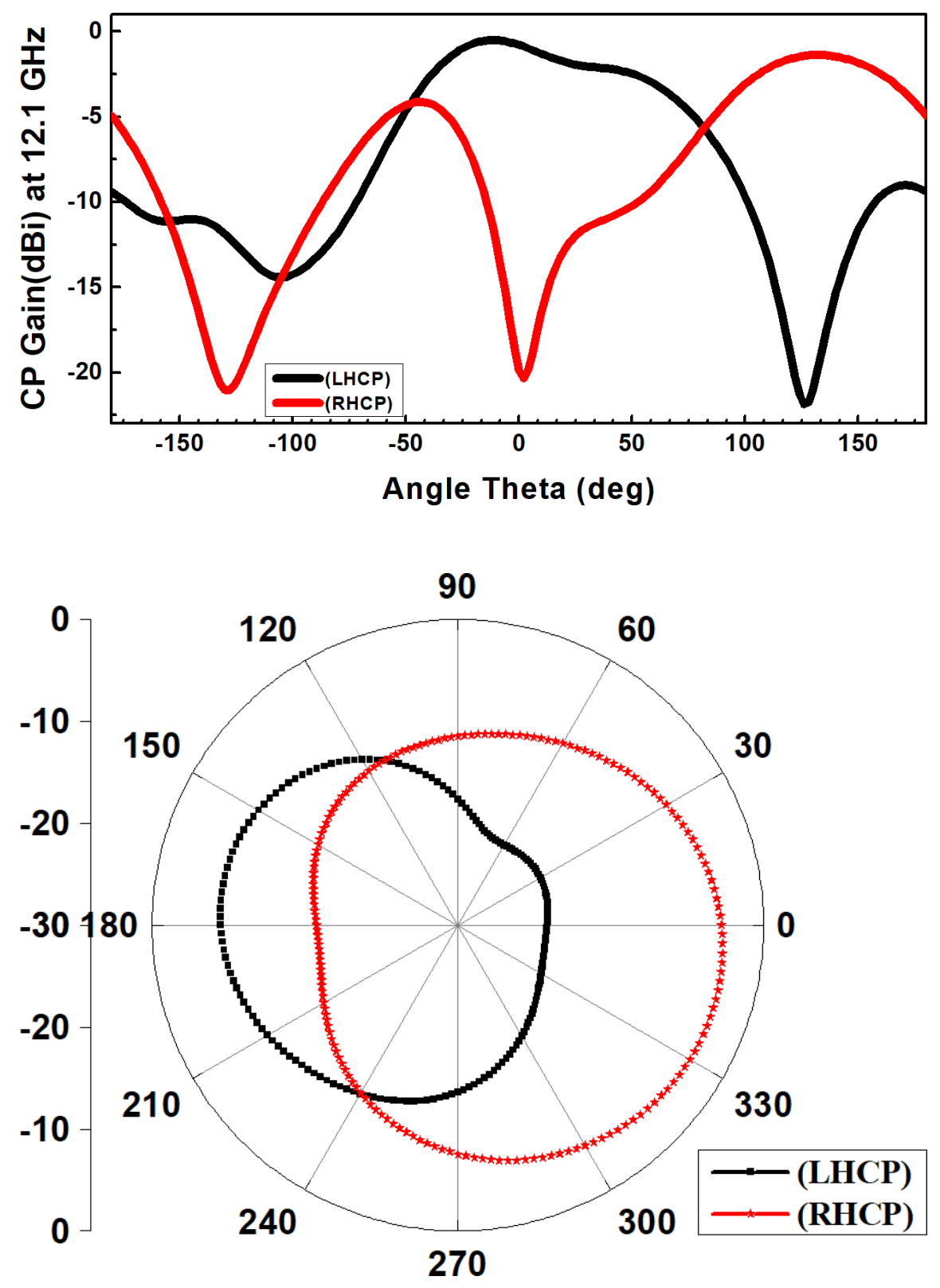

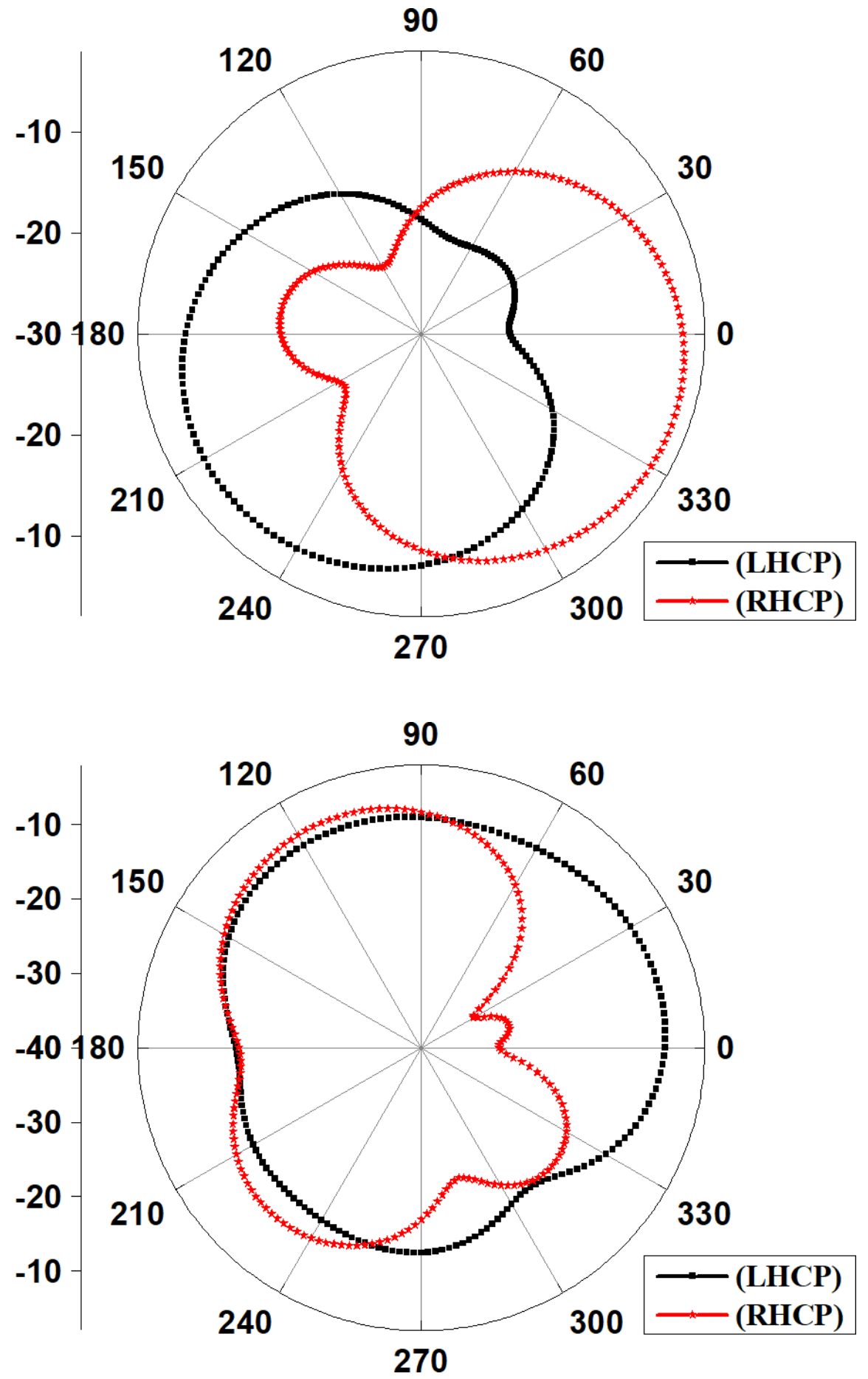

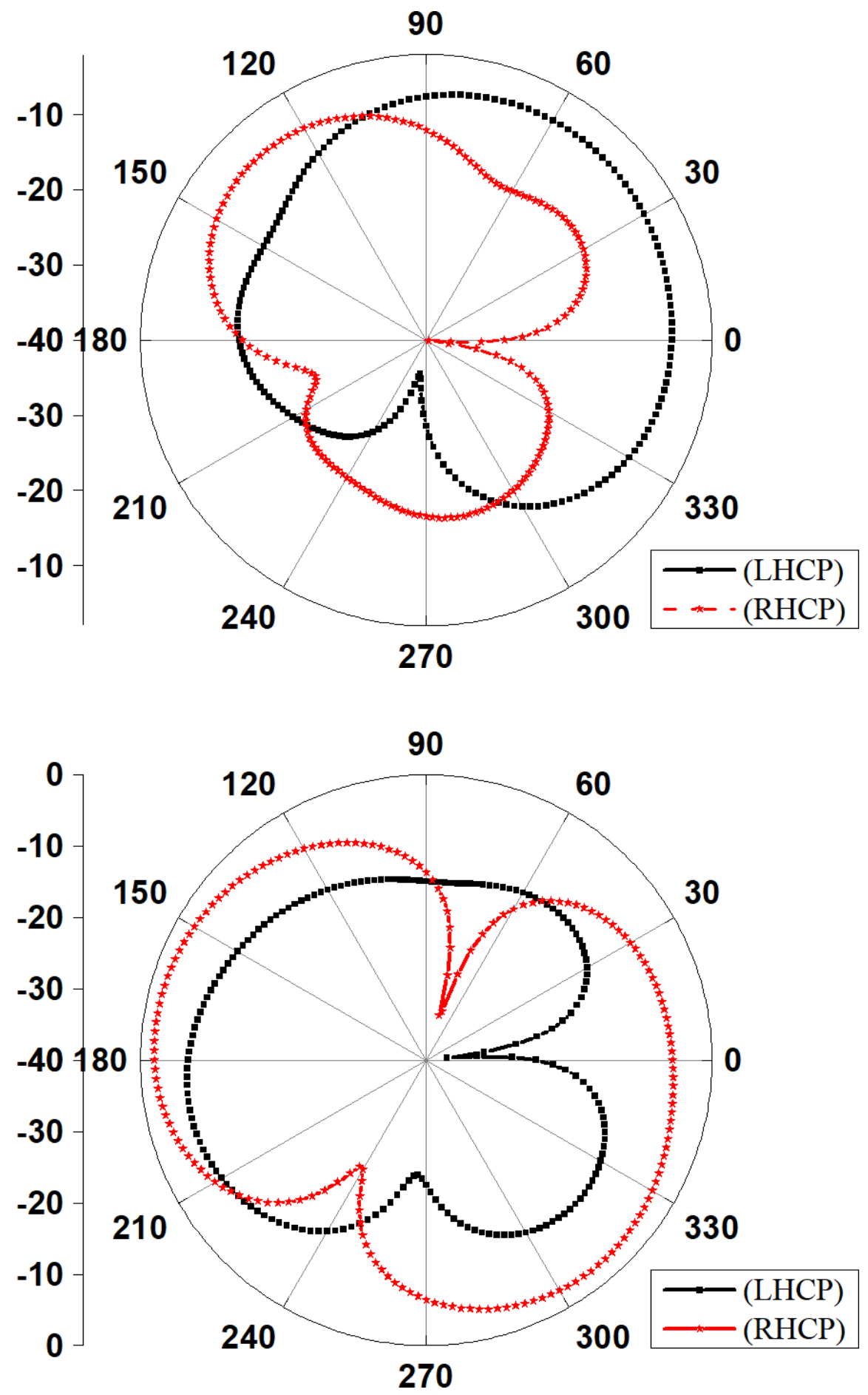

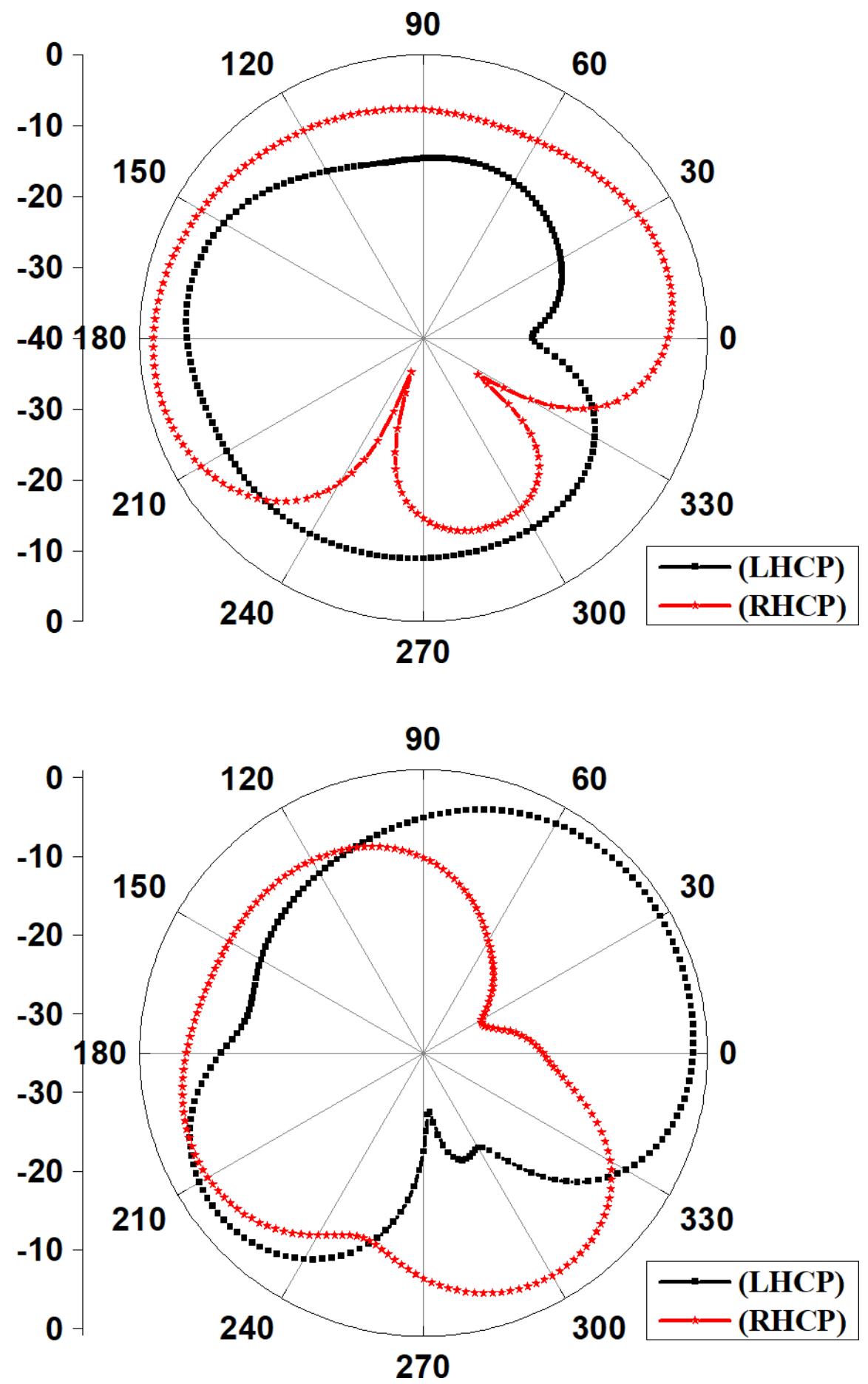

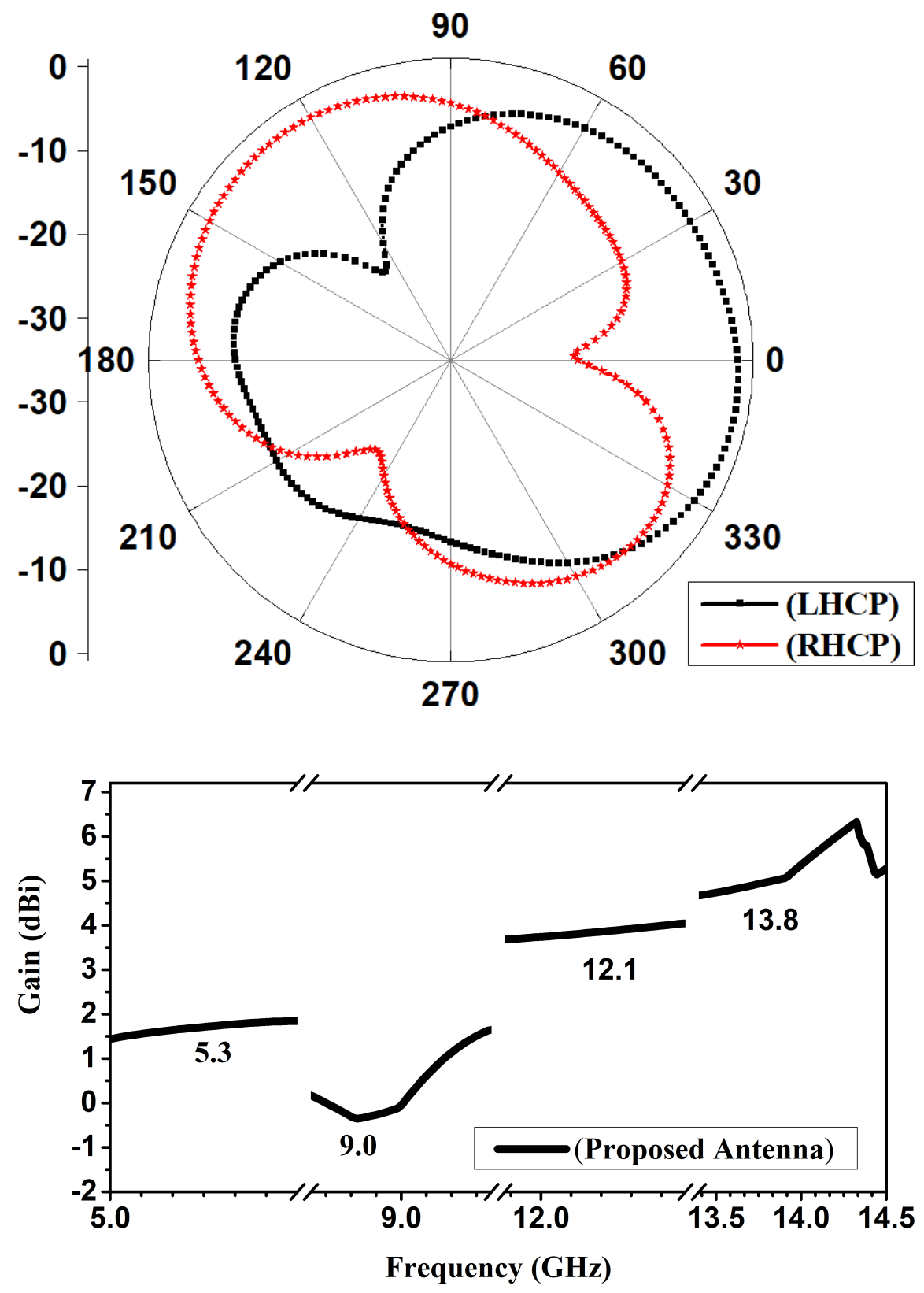

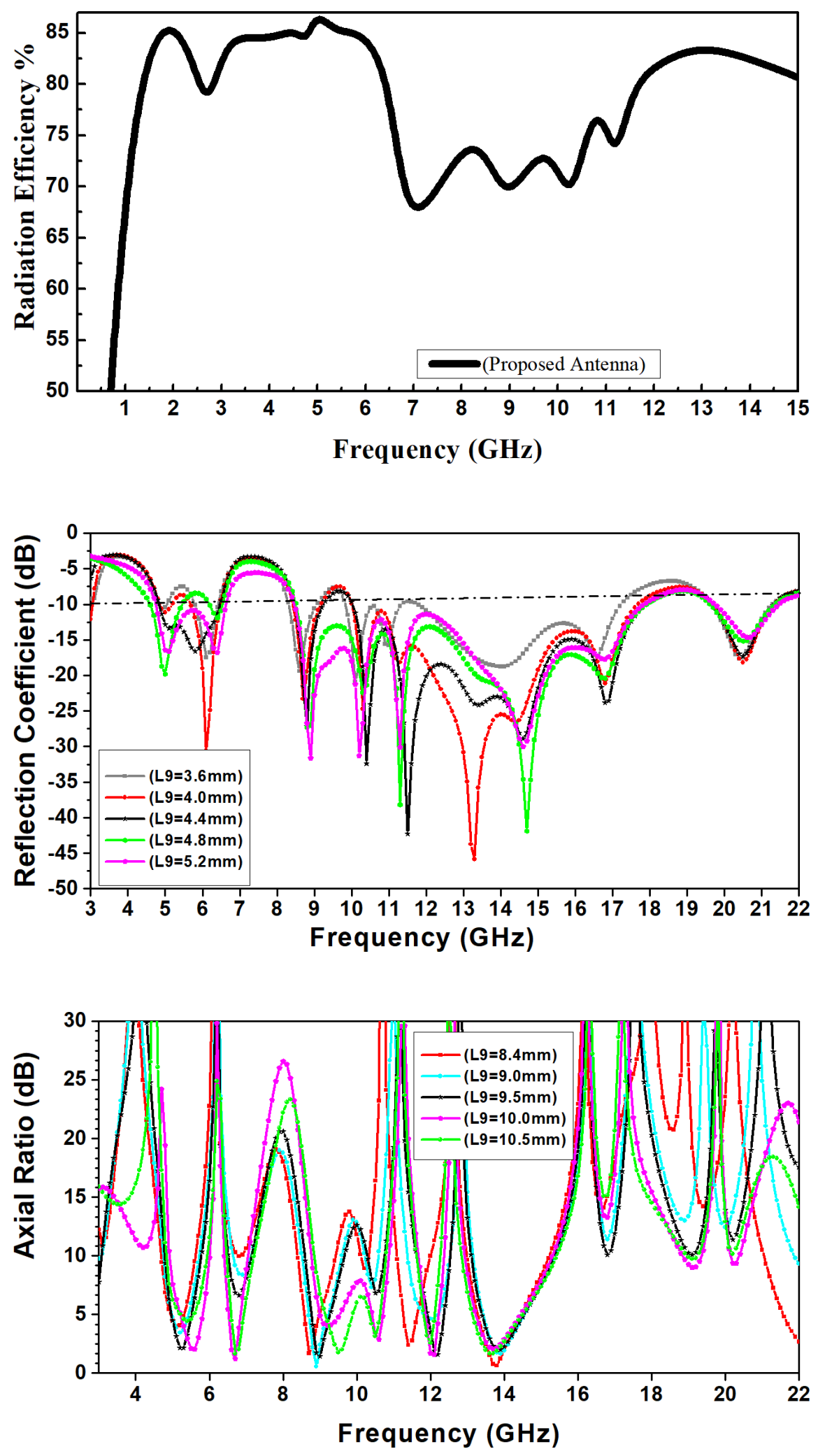

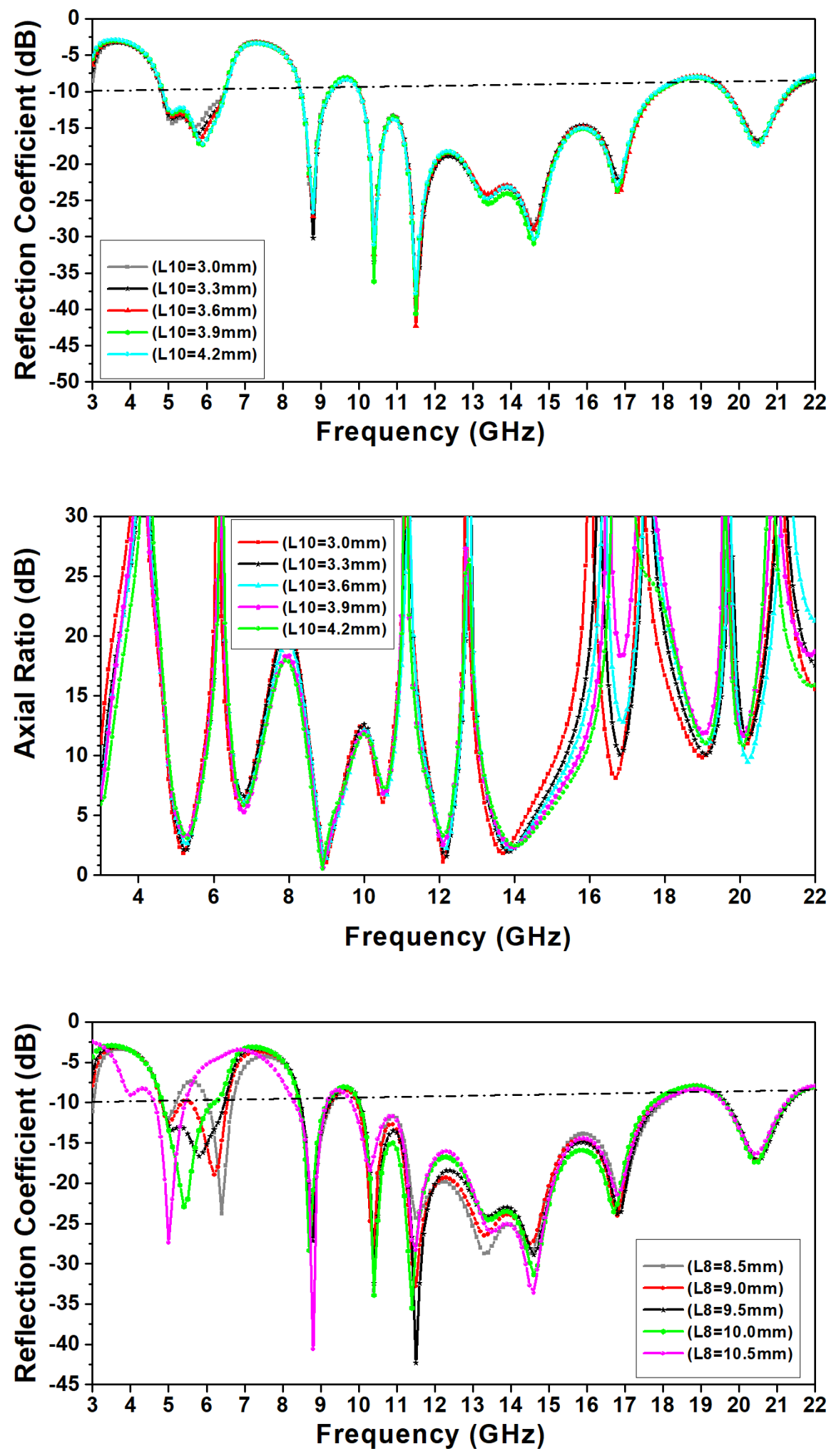

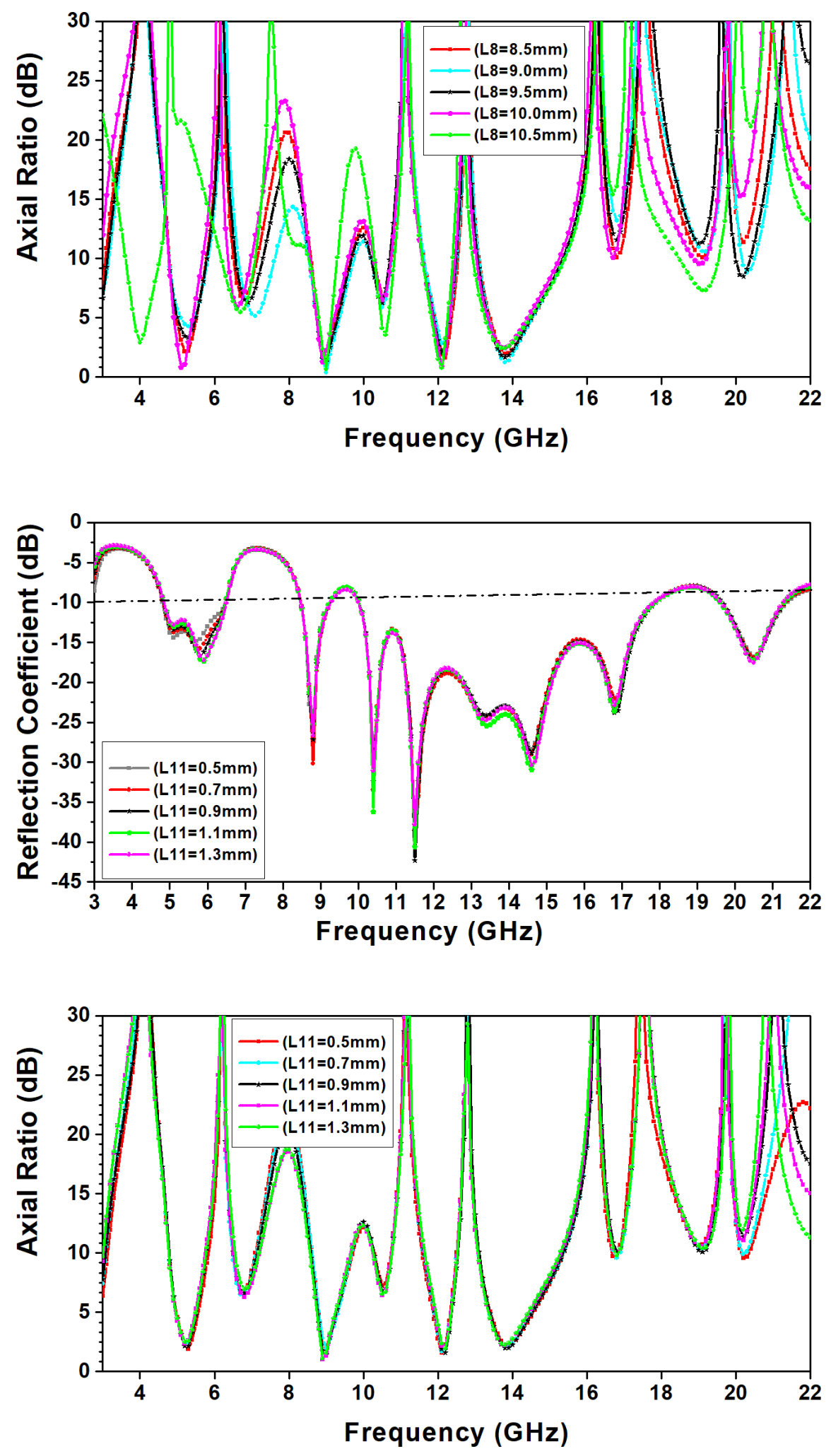